\title{
Effect of Diagenetic Evolution and Hydrocarbon Charging on the Reservoir-Forming Process of the Jurassic Tight Sandstone in the Southern Junggar Basin, NW China
}

\author{
Tianqi Zhou ${ }^{1,2,3}$, Chaodong $\mathrm{Wu}^{2,3, * \mathbb{D}}$, Xutong Guan ${ }^{2,3}$, Jialin Wang ${ }^{2,3}$, Wen Zhu ${ }^{4}$ and Bo Yuan ${ }^{5}$ \\ 1 Research Institute of Petroleum Exploration and Development, PetroChina, Beijing 100083, China; \\ zhoutianqi@petrochina.com.cn \\ 2 Key Laboratory of Orogenic Belts and Crustal Evolution, Ministry of Education, School of Earth and Space \\ Sciences, Peking University, Beijing 100871, China; guanxt@pku.edu.cn (X.G.); jlwang@pku.edu.cn (J.W.) \\ 3 Institute of Oil \& Gas, Peking University, Beijing 100871, China \\ 4 Petroleum Exploration and Production Research Institute, Sinopec, Beijing 100083, China; \\ zhuwen.syky@sinopec.com \\ 5 Geophysics Department in Exploration and Development Institution of Xinjiang Oilfield Company, \\ Urumqi 834000, China; yuanbo123321@petrochina.com.cn \\ * Correspondence: cdwu@pku.edu.cn; Tel.: +86-139-1079-1145
}

\section{check for} updates

Citation: Zhou, T.; Wu, C.; Guan, X.; Wang, J.; Zhu, W.; Yuan, B. Effect of

Diagenetic Evolution and

Hydrocarbon Charging on the Reservoir-Forming Process of the Jurassic Tight Sandstone in the Southern Junggar Basin, NW China Energies 2021, 14, 7832. https:// doi.org/10.3390/en14237832

Academic Editor:

Sohrab Zendehboudi

Received: 25 October 2021

Accepted: 15 November 2021

Published: 23 November 2021

Publisher's Note: MDPI stays neutral with regard to jurisdictional claims in published maps and institutional affiliations.

Copyright: (C) 2021 by the authors Licensee MDPI, Basel, Switzerland. This article is an open access article distributed under the terms and conditions of the Creative Commons Attribution (CC BY) license (https:/ / creativecommons.org/licenses/by/ $4.0 /)$.
Abstract: Deeply buried sandstones in the Jurassic, Toutunhe Formation, are a crucial exploration target in the Junggar Basin, NW China, whereas, reservoir-forming process of sandstones in the Toutunhe Formation remain unknown. Focused on the tight sandstone of the Toutunhe Formation, the impacts of diagenesis and hydrocarbon charging on sandstone reservoir-forming process were clarified based on the comprehensive analysis of sedimentary characteristics, petrography, petrophysical characteristics, and fluid inclusion analysis. Three diagenetic facies developed in the Toutunhe sandstone reservoirs, including carbonate cemented facies (CCF), matrix-caused tightly compacted facies (MTCF), and weakly diagenetic reformed facies (WDF). Except the WDF, the CCF and the MTCF entered the tight state in $18 \mathrm{Ma}$ and $9 \mathrm{Ma}$, respectively. There was only one hydrocarbon emplacing event in sandstone reservoir of the Toutunhe Formation, charging in $13 \mathrm{Ma}$ to $8 \mathrm{Ma}$. Meanwhile, the source rock started to expel hydrocarbons and buoyancy drove the hydrocarbon via the Aika fault belt to migrate into sandstone reservoirs in the Toutunhe Formation. During the end of the Neogene, the paleo-oil reservoir in the Toutunhe Formation was destructed and hydrocarbons migrated to the sandstone reservoirs in the Ziniquanzi Formation; some paleo-oil reservoirs survived in the WDF. The burial pattern and change of reservoir wettability were major controlling factors of the sandstone reservoir-forming process. The buried pattern of the Toutunhe Formation in the western section of the southern Junggar Basin was "slow and shallow burial at early stage and rapid and deep burial at late stage". Hence, pore capillary pressure was extremely low due to limited diagenetic reformation (average pore capillary pressures were $0.26 \mathrm{MPa}$ ). At the same time, high content of chlorite coating increased the lipophilicity of reservoirs. Therefore, hydrocarbons preferably charged into the WDF with low matrix content (average 4.09\%), high content of detrital quartz (average 28.75\%), high content of chlorite films (average 2.2\%), and lower pore capillary pressures (average $0.03 \mathrm{MPa}$ ). The above conditions were favorable for oil and gas enrichment.

Keywords: tight sandstone reservoir; Junggar Basin; diagenetic process; hydrocarbon emplacement; reservoir-forming

\section{Introduction}

The formation mechanism of sandstone reservoirs mainly involves two aspects, namely the reservoir rock formation mechanism and the hydrocarbon emplacementaccumulation mechanism. Owing to its direct influence on the formation mechanism and heterogeneity of sandstone reservoir rocks, diagenesis plays a particularly important 
role in the exploration and development of low-porosity, low-permeability tight sandstone reservoirs. However, different diagenetic processes may have either constructive or destructive effects on the physical property of sandstone reservoirs [1,2]. For instance, compaction is the main contributor to porosity and permeability reduction [2], and it is especially influential in sandstones with higher contents of ductile particles (such as rock fragments, mica, argillaceous clasts, and matrix). In contrast, pressure solution often results in the crushing of brittle minerals and thus the formation of intra-granular fractures [2]. As for clay mineral cementation, its influences on porosity and permeability are more complicated [3-5]. Most researchers believe that authigenic clay minerals are extremely harmful to reservoir quality [6-8]. It is often the case that a small number of authigenic minerals can lead to plugging of pore throats and severely reduce permeability. Nevertheless, some scholars hold the view that the content of authigenic clay minerals may provide a potential reservoir space for sandstone, due to their inter-granular and inter-crystalline pores [9-11]. Moreover, the cover film of clay minerals can to some extent resist compaction, suppress the development of other cement, and thus protect primary pores $[12,13]$. The impact of relatively rigid cement on the reservoir remains controversial; for example, cementation by sparry calcite and quartz is believed by a few scholars to enhance the compressive strength of the sandstone reservoir and hence help to preserve primary pores [14]. However, most researchers pinpoint the more profound destructive effect of high-content rigid cement on the reservoir's physical properties, as it plugs primary pores in the reservoir. Whether dissolution can effectively improve reservoir performance is also debatable at this moment [15-17]. Moreover, it is still unclear when it comes to the controlling factors of the diagenetic modification intensity, and more efforts should be made to investigate the constraints of tectonic and burial processes as well as hydrocarbon emplacement on diagenetic events.

The Junggar Basin is located in the southern part of the Central Asian orogeny, and it is a large-scale superimposed petroliferous basin that is formed during Neogene-Quaternary. The southern margin of the Junggar Basin (hereinafter referred to as the "South Junggar") has oil resources of $1.043 \times 10^{9} \mathrm{~m}^{3}$ and natural gas resources of $5.371 \times 10^{11} \mathrm{~m}^{3}$, which decided the position of the South Junggar as one of the most important fields for hydrocarbon exploration in West China [18]. The discovery of well Gaotan 1, a high-production oil and gas well in the southern Sikeshu Sag, in the western part of the South Junggar, represents a great breakthrough in the exploration of the lower formations of the South Junggar [19]. Similar to the southern Sikeshu Sag, the Kayindike area of the northern Sikeshu Sag is also characterized by the presence of multiple effective source rocks, well-developed highquality cap rocks, and well-aligned large anticlines [20], which are extremely favorable for large-scale hydrocarbon accumulation. Tight sandstone is extensively distributed in the Toutunhe Formation in the Kayindike area [21]. Numerous scholars have characterized the mineral composition, pore-throat configuration, and diagenetic characteristics of the sandstone reservoir in the Toutunhe Formation. However, the development characteristics and formation mechanisms of the high-quality reservoir remain unclear [21-23]. The Toutunhe sandstone in the Kayindike area is characterized by low maturity and high matrix content. Existing research on the effect of the high chlorite content on porosity and permeability is still inconclusive [24,25]. Moreover, the basal zeolite cementation is symbolic of the Toutunhe sandstone, although its genesis and controlling effect on the reservoir performance require future discussion $[26,27]$. Besides, how the high-content carbonate cementation affects the sandstone reservoir also needs further clarification [26,27]. Previous studies have indicated the obvious control of the sedimentary environment on the Jurassic reservoir rocks in the Sikeshu Sag [28-31]. However, they generally fail to consider the effects of diagenetic modification and hydrocarbon emplacement on reservoir quality. Therefore, it is of urgent importance to clearly describe the reservoir-forming mechanism of the Toutunhe sandstone in the Kayindike area to clarify whether or not the reservoir quality and exploration potential of the northern Sikeshu Sag are analogous to those of the southern part. 
This research targets Toutunhe Formation sandstone in the Kayindike area of the Sikeshu Sag, the South Junggar, and the objective is threefold: (1) to illustrate diagenetic processes in different facies and discuss the reasons for sandstone densification; (2) to investigate the temporal sequences of sandstone densification and hydrocarbon emplacement; (3) to reveal the formation process of the Toutunhe sandstone reservoir.

\section{Geological Setting}

The Junggar Basin is surrounded by the Zhayier Mountain and Aerjiati Mountain in the west (the West Junggar Mountains), the Kalamaili Mountain and Qinggelidi Mountain in the east (the East Junggar Mountains), and the Tianshan Mountains in the south (Figure 1). Structurally, it lies in the joint of Kazakhstan, Siberia, and Tarim paleo-plates, and thus is enclosed by the corresponding three Paleozoic suture lines. This basin is a large composite basin formed from the Late Carboniferous to the Quaternary, accompanied by complex structural-sedimentary relations [20,26,32-40]. In terms of the South Junggar, it is tectonically located within the piedmont thrust belt of the North Tianshan in the Central Depression of the Junggar Basin. It extends from Jinghe County in the west to Dashitou area of Mulei County in the east and from the North Tianshan in the south to the Wu-Yi Road in the north. The South Junggar stretches itself along the EW direction, with an NS width of about $200 \mathrm{~km}$.

The Sikeshu Sag in the western part of the piedmont thrust belt of the North Tianshan is bounded by the Tianshan orogeny in the south and the Chepaizi Uplift in the north (Figure 1b). The southern Sikeshu Sag is subjected to intensive tectonic movement and has developed a series of south-dipping high-angle thrust faults. The northern Sikeshu Sag lies in the junction between the Chepaizi Uplift and Sikeshu Sag and has developed the Kayindike anticline. Due to the limited effects of the Paleogene tectonic movement, the Kayindike anticline is found with low uplifting magnitudes. The Aika fault belt in the northern Kayindike anticline occurs in the Early Triassic, of which the shallow structure is modified during the Late Paleogene [39]. It effectively connects the source rock of the Lower Jurassic and the effective reservoir rock of the Upper Jurassic and Ziniquanzi Formation, which is critical to hydrocarbon migration and accumulation in the Kayindike anticline [41].
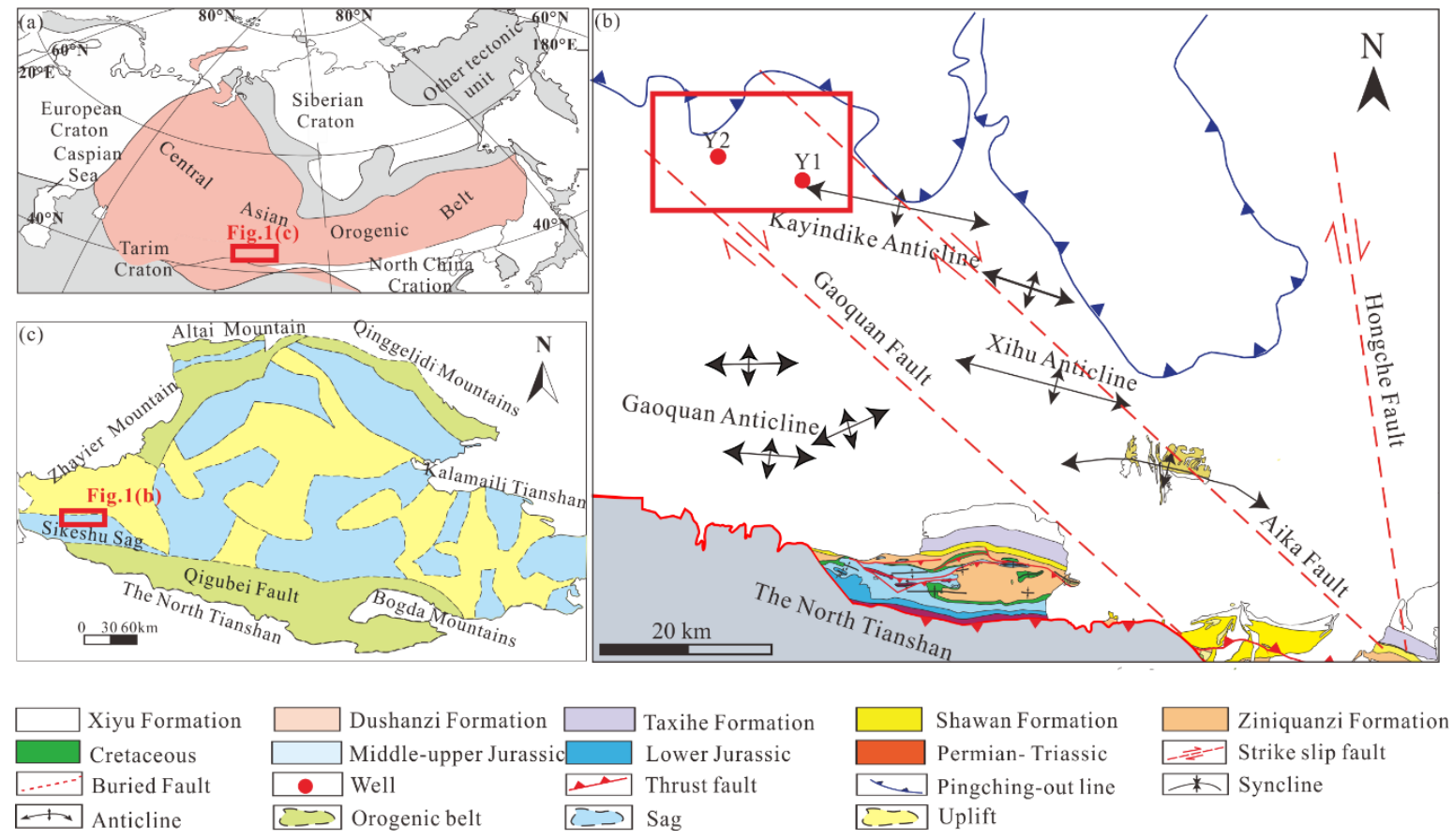

Figure 1. (a) Location of the Central Asian Orogenic Belt and (b) tectonic map of the Sikeshu Sag and location of the study area (modified by [42]); (c) Location of the Sikeshu Sag on the Junggar Basin. 


\section{Samples and Methods}

Twenty-three drilling core samples were derived from the Toutunhe Formation in the Kayindike area (Figures 1 and 2). The sample wells are among the two important exploration wells and all drilling cores are from the braid river channels on the delta plain (Figure 2).

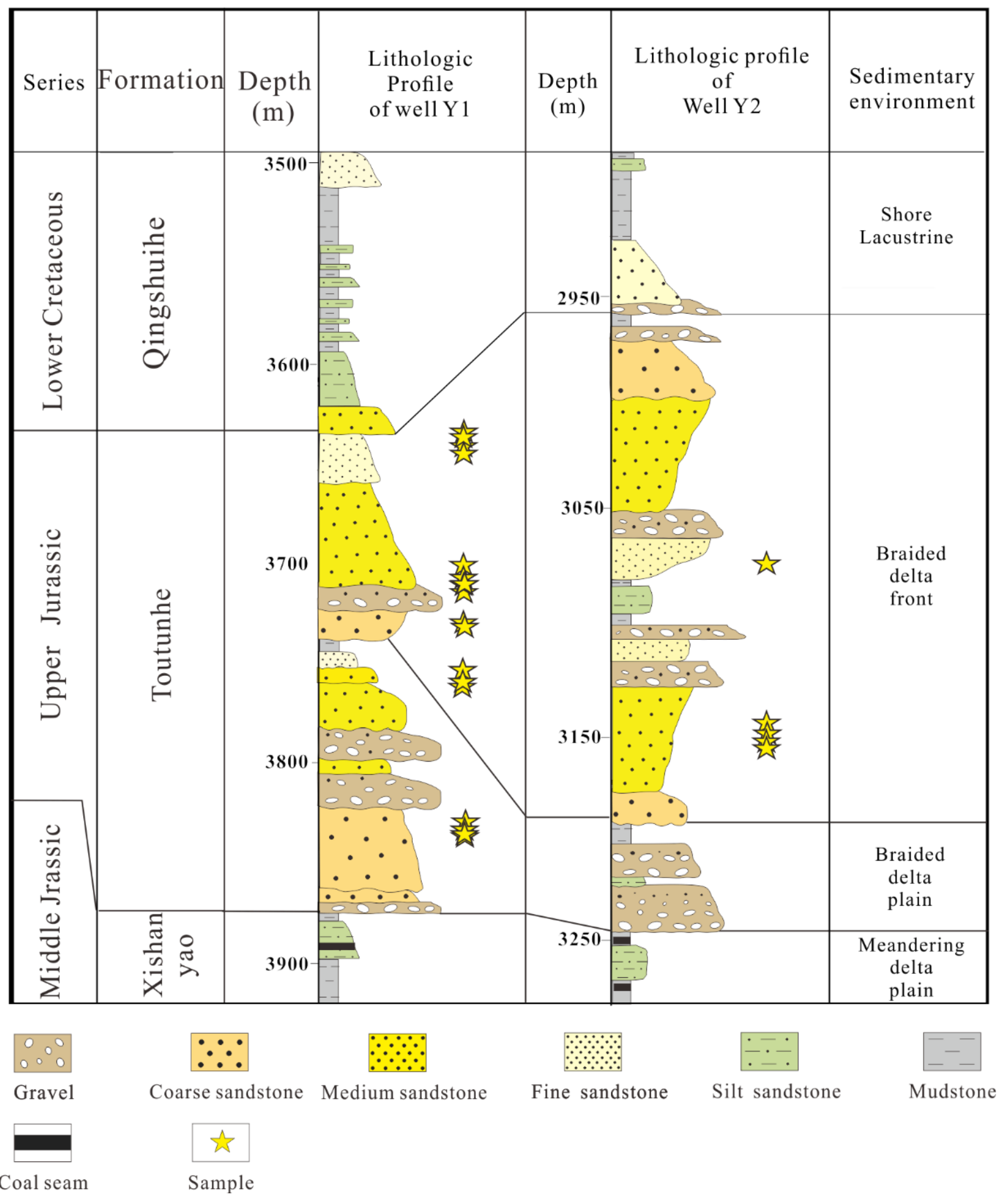

Figure 2. Lithologic profiles and sampling locations of well $Y 1$ and well $Y 2$ drilled in Sikeshu Sag. 


\subsection{Mineral Composition and Morphology Analysis}

The 23 sandstone samples were also made into pore-casted thin sections by injecting blue epoxy resin into the pores. In order to better identify carbonate minerals, half of the pore-casted thin sections were dyed using the Alizarin Red, and the mineral compositions and pore types were determined via the image analysis using the software ImageJ. Meanwhile, whole-rock and clay fraction mineralogy of 23 sandstone samples were measured by $\mathrm{X}$-ray diffraction (XRD) using X-Pert3 Powder 010301 diffractometer set, $\mathrm{Cu} / \mathrm{K} \alpha$ radiation, with voltage of $50 \mathrm{keV}$ and current of $800 \mu \mathrm{A}$. Sample preparation and analyse procedures were modified from $\mathrm{Xi}$ [43], which was according to the Chinese Oil and Gas Industry Standard (SY/T) 5163-2014.

For the 12 sandstone samples with severe carbonate cementation, the carbonate cementation stages were identified according to their cathode luminescence (CL) features. CL images were derived from a Leica DM2500P digital transmission microscope with a Cambridge Image Technology's CL8200 MK5-2 detector. The acceleration voltage was $30 \mathrm{KV}$ and beam current was $2 \mathrm{~mA}$ under vacuum conditions.

FEI Quanta-650 FEG scanning electron microscopy and energy dispersive spectrometer (EDS) were applied for mineral morphology and diagenetic sequence analysis. Mineral geochemistry analysis of 12 samples with multi-stage carbonate cements, zeolite cements, and quartz cements were tested using a JEOL JXA-8230 electron microprobe with an accelerating voltage of $30 \mathrm{keV}$ and beam current of $0.01 \mu \mathrm{A}$. The beam size ranged from $3 \mu \mathrm{m}$ to $5 \mu \mathrm{m}$ according to mineral size.

\subsection{Petrophysical Parameters}

Helium porosity and air permeability of 23 sandstone core plugs were measured from the CMS-300 Core measurement system under a confining pressure of $6 \mathrm{MPa}$, in accordance with the Chinese Oil and Gas Industry Standard (SY / T) 6385-1999 and 5346-1994, respectively. Oil saturation of 18 sandstone samples were obtained on the core under sealed coring conditions, using Oil-Check 400 tester. The contact angles of 18 sandstones were acquired with SAT-5100 Balance Performance Monitor according to the Chinese Oil and Gas Industry Standard (SY/T) 5153-1999.

\subsection{Fluid Inclusion Analysis}

The petrography, fluorescence characteristics, and microthermometry of 136 oilaqueous inclusion pairs and 136 oil-gas inclusions were obtained in this paper. Sixteen sandstones samples were prepared as doubly polished thin sections whose thickness are $70 \mu \mathrm{m}$ around. Homogenization temperature (Th) of 184 aqueous inclusions (129 aqueous inclusions developed in the quartz overgrowth, 55 aqueous inclusions developed in the micro-fractures of the detrital quartz) were measured by a calibrated Linkam THMSG 600 heating and cooling stage that enabled temperatures of phase transitions in the range of $-196^{\circ} \mathrm{C}-600{ }^{\circ} \mathrm{C}$. The rate of heating and cooling was $5^{\circ} \mathrm{C} / \mathrm{min}$ and the experimental precision of Th was $0.1{ }^{\circ} \mathrm{C}$. Fluorescence characteristics of 125 oil-gas filled inclusions were observed with both incident ultraviolet light (UV) and transmitted white light using a Zeiss AxioscopeA1 A Pol microscope. The wavelength of the emission fluorescence was greater than $420 \mathrm{~nm}$. The fluorescence spectra of oil-gas filled inclusions were derived using the HORIBA IHR550 imaging spectrometer.

\subsection{Carbon and Oxygen Stable Isotope Analysis}

Carbon and oxygen isotope analyses of 12 samples with high proportion of carbonate cements were conducted. Samples were ground below 200 mesh and then filtered through a 400-mesh sieve. Then, the $\mathrm{CO}_{2}$ was derived by a series of reactions according to Morad [44]. The carbon and oxygen isotopes of $\mathrm{CO}_{2}$ were measured using Finnigan Mat 250 mass spectrometer. The Vienna Peedee belemnite (VPDB) standard was used for the carbon isotope analysis and the Vienna Standard Mean Ocean Water (SMOW) standard was used for the oxygen isotope analysis. The accuracies of the carbon and oxygen isotope ratios 
were $\pm 0.2 \%$ and $\pm 0.3 \%$, respectively. The relation between the oxygen isotope ratios using the PDB standard and the oxygen isotope in SMOW standard was according to the following equation [45]:

$$
\delta^{18} \mathrm{O}_{\mathrm{v}-\mathrm{SMOW}}=1.03086 \times \delta^{18} \mathrm{O}_{\mathrm{v}-\mathrm{PDB}}+30.86
$$

where $\delta^{18} \mathrm{O}_{\mathrm{v}-\mathrm{SMOW}}$ is oxygen isotopic ratios from SNOW (\%o), $\delta^{18} \mathrm{O}_{\mathrm{v}-\mathrm{PDB}}$ is oxygen isotopic ratios from VPDB $(\%)$.

The cementation temperatures of calcite were calculated by Luo ([46]; $\delta 18 \mathrm{O}$ water $=-3 \% \mathrm{SMOW}$ ):

$$
\mathrm{T}=16.9-4.38 \times\left(\delta^{18} \mathrm{O}_{\mathrm{cal}} \mathrm{PDB}-\delta^{18} \mathrm{O}_{\text {water }} \mathrm{SNOW}\right)+0.1 \times\left(\delta^{18}{ }_{\text {cal }} \mathrm{PDB}-\delta^{18} \mathrm{O}_{\text {water }} \mathrm{SNOW}\right)^{2}
$$

where $\mathrm{T}$ is temperature $\left({ }^{\circ} \mathrm{C}\right), \delta^{18} \mathrm{O}_{\mathrm{cal}} \mathrm{PDB}$ is oxygen isotopic ratios from SNOW of calcite $(\%), \delta^{18} \mathrm{O}_{\text {water }} \mathrm{SNOW}$ is oxygen isotopic ratios from SNOW of ancient lake (\%).

\section{Results}

Based on the diagenetic characteristics and pore structures of the Toutunhe Formation sandstone in the Kayindike area, this research discussed the mineral composition, sandstone texture, physical property, and reservoir space of three facies, accompanied by reconstruction of the hydrocarbon emplacement process.

\subsection{Lithology and Petrophysical Properties of Three Lithofacies}

The Toutunhe Formation sandstone in the Kayindike area is often characterized by low composition maturity, limited dissolution intensity, low cement content, and highly varied matrix contents. Lithic sandstone and arkose-lithic sandstone are the most common in the study area. The quartz content is low, ranging from $27.92 \%$ to $36.32 \%$. The feldspar content varies greatly from $3.1 \%$ to $22.56 \%$, with plagioclase content of $1.5 \%$ to $16.324 \%$ and a potassium feldspar content of $1 \%$ to $8.36 \%$. The rock fragments content is relatively high, and it is mainly composed of sedimentary and magmatic rock fragments, with few metamorphic rock fragments. The matrix content also changes greatly, ranging from $1.2 \%$ to $16.2 \%$. Moreover, the sandstone is found with a low cement content, mainly consisting of carbonate, zeolite, and authigenic clay mineral cementation, and an extremely limited amount of quartz cementation. The carbonate cement, accounting for $0 \%$ to $20.29 \%$ of the total minerals, is mostly composed of calcite, ferrocalcite, and ferrodolomite. The zeolite cement, primarily attributed to the analcite and laumontite, is found with a content of $0.46 \%$ to $3.25 \%$. Authigenic clay minerals (mainly chlorite, illite, and kaolinite) are fewer on an overall basis, with an average content of $4.39 \%$.

Due to the relatively low intensity of the diagenetic modification, the Toutunhe sandstone has relatively good physical properties, and a solid positive correlation exists between porosity and permeability (Figure 3a). However, some sandstone presents high contents of matrix and carbonate cement, which severely damages the original reservoir space. According to the diagenetic modification condition, the Toutunhe sandstone in the Kayindike area can be divided into three facies, namely carbonate-cemented facies (CCF), matrix-caused tightly-compacted facies (MTCF), and weakly diagenetically-reformed facies (WDF). The porosity and permeability of the weakly diagenetically-reformed facies are far better than those of the other facies, as indicated by the mineral composition heat map, physical property characteristics, and compaction-cementation chart (Figure 3). 

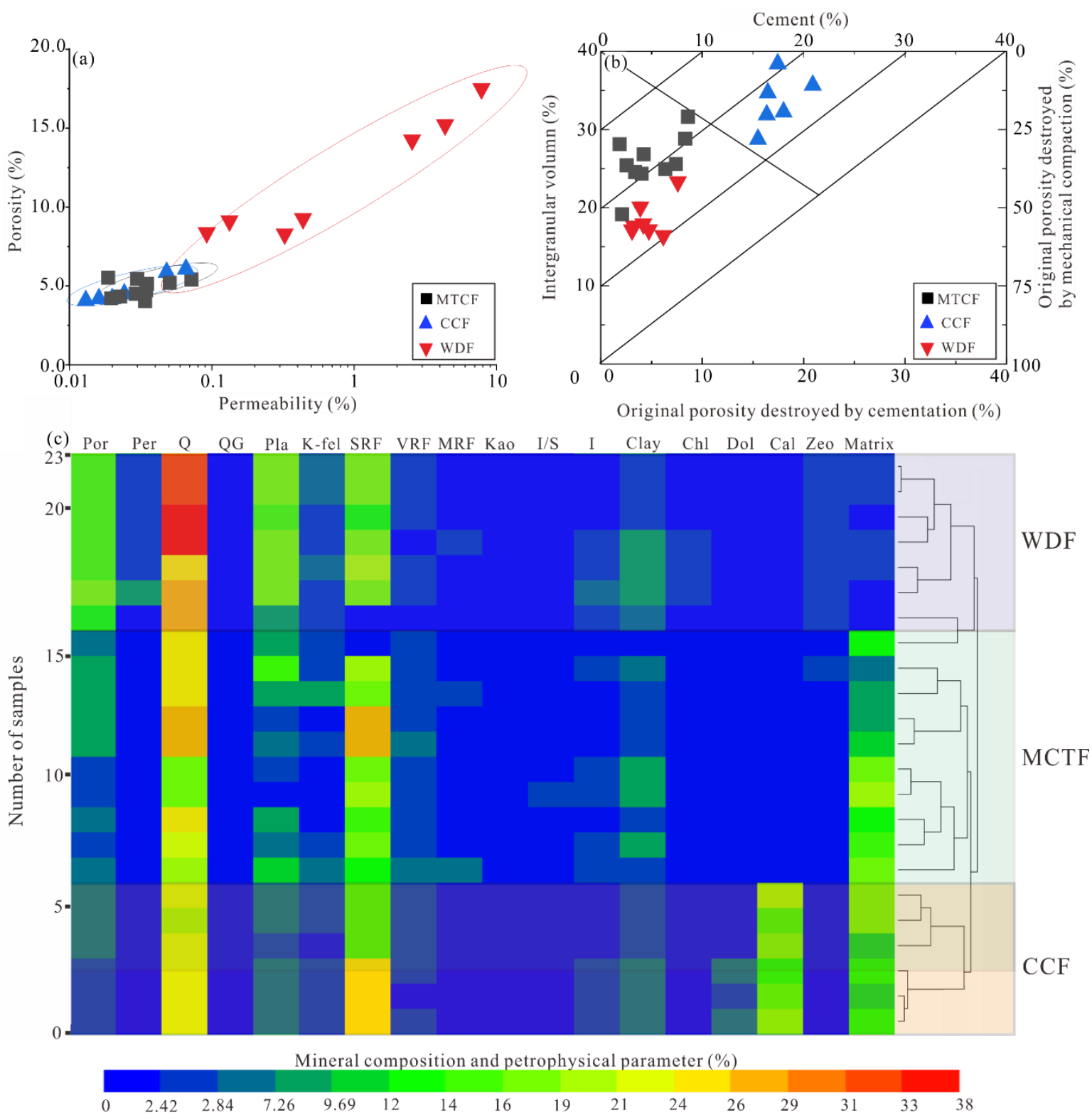

Figure 3. Petrophysical parameters, the original porosity destroyed by cementation and mechanical compaction, and mineral characteristics of three sandstone facies developed in the Toutunhe Formation: (a) Relation of porosity and permeability, (b) Plot of cement volume versus intergranular volume in Toutunhe sandstones, (c) The heat map of mineral composition and petrophysical parameters. Q, quartz; QG, quartz overgrowth; Pla, plagioclase; K-fel, potassium feldspar; MRF, metamorphic rock fragment; VRF, volcanic rock fragment; SRF, sedimentary rock fragment; Cal, calcite; Sid, siderite; Chl, chlorite; I, illite; Kao, kaolinite; Sid, siderite; I/S illite-smectite mixed layer; Zeo: zeolite.

The WDF features a high content of detrital quartz and zeolite and the development of chlorite films (Figure $4 a-c$ ). The flaky chlorite film often occurs on the surfaces of the feldspar and magmatic rock fragment particles. The WDF is typically well sorted and rounded, with high texture maturity. It is commonly seen in sandstone deposits in the environments of shore-lake, mouth bar, and underwater distributary channel. The CCF mostly presents itself as the basal cementation of calcite, and the content of ferrocalcite and ferrodolomite in the Toutunhe Formation is less than that in the Badaowan Formation (Figure $4 \mathrm{~d}-\mathrm{g}$ ). The MTCF is often developed at the base of the braided river channel. With a relatively high matrix content, this facies is mostly of fine-grain sandstone and is mainly characterized by poor sorting and rounding (Figure $4 \mathrm{~h}, \mathrm{i}$ ). More details about the three and Table 1 types of Toutunhe sandstone facies in the Kayindike area are pro- 
vided in Figures 3 and 4, including mineral composition, reservoir space, and porosity and permeability.
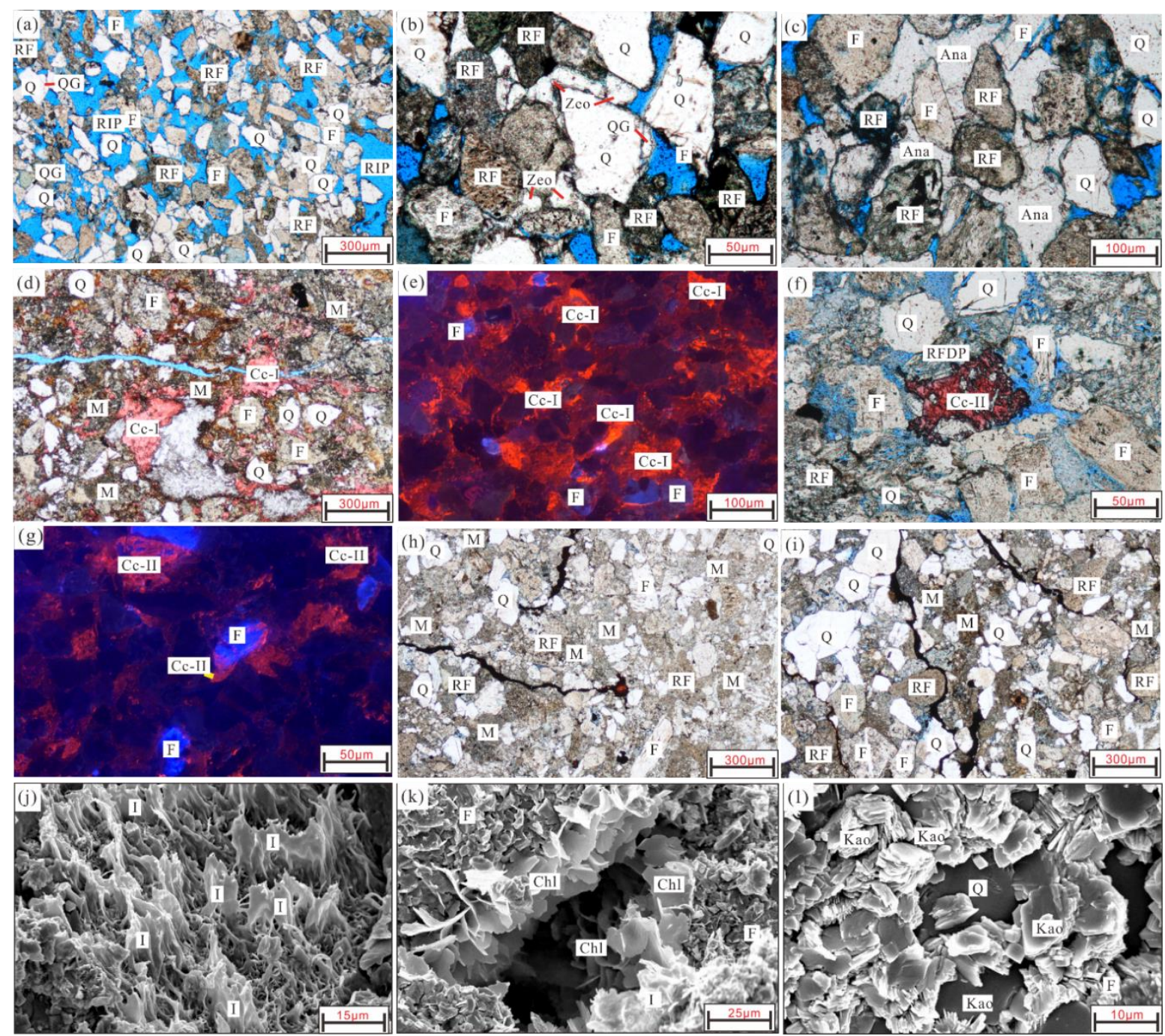

Figure 4. Casting thin sections of the tight sandstone samples in Toutunhe Formation, showing mainly diagenetic characteristics of 3 types of lithofacies. (a) weakly diagenetic reformed facies, residual intergranular pores widely developed with weakly dissolved, 3643.2 m, Y1 well, plane-polarized light; (b) weakly diagenetic reformed facies, analcime filled in residual intergranular pore, $3643.2 \mathrm{~m}$, Y1 well, plane-polarized light; (c) poikilitic analcime filling in residual intergranular pores, 3907.4 m, Y1 well, plane-polarized light; (d) carbonate cemented facies, poikilitic calcite filling the residual intergranular pores, cut by fractures, $3809.5 \mathrm{~m}$, Y1 well, plane-polarized light; (e) carbonate cemented facies, poikilitic calcite emitting bright orange fluorescence, $3809.5 \mathrm{~m}$, Y1 well, cathodoluminescence image; (f) carbonate cemented facies, ferrocalcite occluding the dissolution pore of rock fragment, $3182.3 \mathrm{~m}$, well Y2, plane-polarized light; (g) ferrocalcite emits dark orange fluorescence, $3809.8 \mathrm{~m}$, well Y1, cathodoluminescence image; (h) matrix with a widely developed but small proportion of residual intergranular pores, most of micro-fractures were filled with bitumen, $3182 \mathrm{~m}$, well Y2, plane-polarized light; (i) pore-filling matrix widely developed, most of micro-fractures were filled with bitumen, $3181 \mathrm{~m}$, well $\mathrm{Y} 2$, plane-polarized light; (j) fibrous illite developed on the mineral grain, 3709 m, Y1 well, SEM; (k) Lining-blade shape chlorite, $3809.1 \mathrm{~m}, \mathrm{Y} 1$ well, SEM; (1) kaolinite aggregates in book-page shape filled primary pores, $3643.2 \mathrm{~m}$, well X1, SEM. Q: quartz; QG: quartz overgrowth; F: feldspar; MRF: metamorphic rock fragment; VRF: volcanic rock fragment; SRF: sedimentary rock fragment; RF: rock fragment; Cal-I: calcite; Cal-II: ferrocalcite; Sid: siderite; C: chlorite; Kao: kaolinite; I: illite; Zeo: zeolite; M: matrix; RIP: residual inter-granular pore; MP: matrix pores: FDP: feldspar dissolution pores; RFDP: rock fragment dissolution pores; IPC: intercrystalline pores of clay; CIP: clay mineral intergranular pore. 


\subsection{Pore Types}

Owing to the limited dissolution-induced alteration and cementation, the residual inter-granular pore often preserves its complete shape, with relatively flat boundaries. The radius of residual inter-granular pores lies between $0.855 \mu \mathrm{m}$ and $80.364 \mu \mathrm{m}$ (Figure $4 \mathrm{a}-\mathrm{c}$ ). The volume ratio of residual inter-granular pores is relatively high, which is commonly higher than $70 \%$ for the WDF. Feldspar dissolution pores generally occur in the potassium feldspar and the dissolution pore volume ratio in the plagioclase is smaller than that in the potassium feldspar. Such pores, often strip-like, are distributed along the feldspar cleavage, with the radii mostly of $0.951 \mu \mathrm{m}$ to $10.429 \mu \mathrm{m}$ and volume ratios of $4.2 \%$ to $16.4 \%$. Rock fragment dissolution pores, generally irregularly shaped, are finer than feldspar dissolution pores, with a radius range of $0.155 \mu \mathrm{m}$ to $4.024 \mu \mathrm{m}$. Dissolution pores in the Toutunhe sandstone are associated with a volume ratio of $4.8 \%$ to $19.0 \%$. Inter-granular and intercrystalline pores of clay minerals grow with the increasing content of authigenic clay minerals, and their shapes are often affected by the morphology of authigenic clay minerals (Figure $4 \mathrm{j}-1)$. The radius of the clay mineral inter-granular pore is $0.136 \mu \mathrm{m}$ to $1.383 \mu \mathrm{m}$, while that of the clay mineral inter-crystalline pore is in most cases smaller than $0.124 \mu \mathrm{m}$. The volume ratio of the clay mineral inter-granular pore in the Toutunhe sandstone is $5.12 \%$ to $19.2 \%$, while that of the clay mineral inter-crystalline pore is $1.3 \%$ to $9.0 \%$. At last, the matrix pore, which is often amorphous, typically features a narrow radius and yet a high pore volume ratio. The presence of extensive matrix pores further complicates the pore structure. In the Toutunhe sandstone, the volume ratio of matrix pores is relatively low, ranging from $0.32 \%$ to $89.1 \%$. In addition, the Toutunhe sandstone is relatively fractured, due to compaction and tectonic movement. The resultant fractures are often found as networked, irregularly shaped, or nearly-vertical (with high dip angles), and their geneses are related to the uplifting of the Tianshan Mountain during the Middle-Late Jurassic. During the Toutunhe period, folding-associated deformation as well as uplifting and denudation are very common in the Sikeshu Sag. During this time, the Chemo paleo-uplift is formed, and fractures are created mainly by the tectonic compressional stress imposed on formations. Nonetheless, the fractures in the Toutunhe sandstone are mostly filled with calcite and bitumen and thus have limited contributions to improving the reservoir's physical property. The pore volume ratios, corresponding contributions to porosity and pore radius for the six types of pores in the Toutunhe Formation sandstone are presented in detail in Table 2. 
Table 1. Average petrophysical parameters and mineralogical compositions of three lithofacies (Sample number: 23).

\begin{tabular}{|c|c|c|c|c|c|c|c|c|c|c|c|c|c|c|c|c|c|c|}
\hline \multirow{3}{*}{ Lithofacies } & \multicolumn{7}{|c|}{ Detrital Mineral (\%) } & \multicolumn{3}{|c|}{ Carbonate (\%) } & \multicolumn{4}{|c|}{ Authigenic Clay (\%) } & \multirow{3}{*}{$\begin{array}{c}\text { Zeolite } \\
(\%)\end{array}$} & \multirow{3}{*}{$\begin{array}{l}\text { Matrix } \\
(\%)\end{array}$} & \multicolumn{2}{|c|}{$\begin{array}{l}\text { Petrophysical } \\
\text { Parameters }\end{array}$} \\
\hline & \multicolumn{2}{|c|}{ Quartz } & \multicolumn{2}{|c|}{ Feldspar } & \multicolumn{3}{|c|}{ Rock Fragment } & \multirow[b]{2}{*}{ Siderite } & \multirow[b]{2}{*}{ Calcite } & \multirow[b]{2}{*}{ Ferrocalcite } & \multirow[b]{2}{*}{ Illite } & \multirow{2}{*}{$\begin{array}{c}\mathrm{I} / \mathrm{S} \\
\text { Mix-ed } \\
\text { Layers }\end{array}$} & \multirow[b]{2}{*}{ Kaolinite } & \multirow[b]{2}{*}{ Chlorite } & & & & \\
\hline & $\begin{array}{l}\text { Detrital } \\
\text { Quartz }\end{array}$ & $\begin{array}{c}\text { Quartz } \\
\text { Over- } \\
\text { Growth }\end{array}$ & K-Feldspar & Plagioclase & $\begin{array}{l}\text { Sedimentary } \\
\text { Rock } \\
\text { Fragment }\end{array}$ & $\begin{array}{l}\text { Igneous } \\
\text { Rock } \\
\text { Fragment }\end{array}$ & $\begin{array}{l}\text { Metamorphic } \\
\text { Rock } \\
\text { Fragment }\end{array}$ & & & & & & & & & & $\begin{array}{l}\text { Porosity } \\
(\%)\end{array}$ & $\begin{array}{l}\text { bility } \\
\text { (mD) }\end{array}$ \\
\hline MTCF & 21.37 & 0.13 & 3.50 & 6.33 & 15.92 & 3.67 & 2.35 & 0.00 & 0.00 & 0.00 & 2.90 & 0.82 & 1.35 & 0.75 & 1.20 & 16.33 & 4.98 & 0.04 \\
\hline CCF & 21.50 & 0.12 & 2.88 & 6.38 & 20.01 & 2.79 & 1.47 & 0.00 & 10.13 & 1.50 & 2.27 & 0.20 & 1.23 & 0.96 & 1.59 & 13.76 & 4.95 & 0.04 \\
\hline WDF & 28.75 & 0.96 & 4.68 & 13.14 & 19.47 & 3.59 & 1.26 & 0.00 & 0.00 & 0.00 & 2.81 & 0.07 & 0.43 & 2.34 & 2.57 & 4.09 & 13.04 & 2.77 \\
\hline
\end{tabular}

Table 2. The proportion, porosity, and average pore radius of different pore types in the Toutunhe Formation (Samples number: 13).

\begin{tabular}{|c|c|c|c|c|c|c|c|c|c|c|c|c|c|c|c|c|c|c|}
\hline \multirow[b]{2}{*}{$\begin{array}{l}\text { Samples } \\
\text { Form } \\
\text { Well Y1 }\end{array}$} & \multicolumn{6}{|c|}{ Proportion (\%) } & \multicolumn{6}{|c|}{ Porosity (\%) } & \multicolumn{6}{|c|}{ Average Pore Radius $(\mu \mathrm{m})$} \\
\hline & $\begin{array}{l}\text { Residual } \\
\text { Intergra- } \\
\text { nular } \\
\text { Pore } \\
\text { (RIP) }\end{array}$ & $\begin{array}{l}\text { Feldspar } \\
\text { Dissolu- } \\
\text { tion } \\
\text { Pore } \\
\text { (FDP) }\end{array}$ & $\begin{array}{c}\text { Rock } \\
\text { Fragment } \\
\text { Dissolution } \\
\text { Pore } \\
\text { (RFDP) }\end{array}$ & $\begin{array}{c}\text { Clay } \\
\text { Mineral } \\
\text { Intergranu- } \\
\text { lar Pore } \\
\text { (CIP) }\end{array}$ & $\begin{array}{l}\text { Intercrys- } \\
\text { talline } \\
\text { Pores of } \\
\text { Clay } \\
\text { (IPC) }\end{array}$ & $\begin{array}{l}\text { Matrix } \\
\text { Pore } \\
\text { (MP) }\end{array}$ & $\begin{array}{c}\text { Residual } \\
\text { Inter- } \\
\text { granular } \\
\text { Pore } \\
\text { (RIP) }\end{array}$ & $\begin{array}{c}\text { Feldspar } \\
\text { Dissolu- } \\
\text { tion } \\
\text { Pore } \\
\text { (FDP) }\end{array}$ & $\begin{array}{c}\text { Rock } \\
\text { Fragment } \\
\text { Dissolution } \\
\text { Pore } \\
\text { (RFDP) }\end{array}$ & $\begin{array}{c}\text { Clay } \\
\text { Mineral } \\
\text { Intergranu- } \\
\text { lar Pore } \\
\text { (CIP) }\end{array}$ & $\begin{array}{l}\text { Intercrys- } \\
\text { talline } \\
\text { Pores of } \\
\text { Clay } \\
\text { (IPC) }\end{array}$ & $\begin{array}{l}\text { Matrix } \\
\text { Pore } \\
\text { (MP) }\end{array}$ & $\begin{array}{c}\text { Residual } \\
\text { Intergra- } \\
\text { nular } \\
\text { Pore } \\
\text { (RIP) }\end{array}$ & $\begin{array}{l}\text { Feldspar } \\
\text { Dissolu- } \\
\text { tion } \\
\text { Pore } \\
\text { (FDP) }\end{array}$ & $\begin{array}{c}\text { Rock } \\
\text { Fragment } \\
\text { Dissolution } \\
\text { Pore } \\
\text { (RFDP) }\end{array}$ & $\begin{array}{c}\text { Clay } \\
\text { Mineral } \\
\text { Intergranu- } \\
\text { lar Pore } \\
\text { (CIP) }\end{array}$ & $\begin{array}{l}\text { Intercry- } \\
\text { stalline } \\
\text { Pores } \\
\text { of Clay } \\
\text { (IPC) }\end{array}$ & $\begin{array}{l}\text { Matrix } \\
\text { Pore } \\
\text { (MP) }\end{array}$ \\
\hline 3833.2 & 3.965 & 4.978 & 0.872 & 19.227 & 4.669 & 66.174 & 0.215 & 0.270 & 0.047 & 1.043 & 0.253 & 3.589 & 12.534 & 6.345 & 3.524 & 0.324 & 0.040 & 0.010 \\
\hline 3835 & 5.894 & 4.384 & 1.307 & 15.086 & 8.962 & 64.366 & 0.247 & 0.184 & 0.055 & 0.631 & 0.375 & 2.694 & 13.263 & 7.234 & 4.024 & 0.355 & 0.050 & 0.035 \\
\hline 3834.7 & $\begin{array}{l}0.074 \\
4.324\end{array}$ & 4.432 & 0.352 & 16.435 & 5.363 & $\begin{array}{l}09.090 \\
69.094\end{array}$ & 0.173 & 0.177 & 0.014 & 0.657 & 0.215 & $\begin{array}{l}2.074 \\
2.764\end{array}$ & 16.324 & 3.253 & 3.242 & 0.734 & 0.060 & 0.047 \\
\hline 3760.3 & 0.392 & 4.212 & 1.974 & 4.800 & 0.100 & 89.051 & 0.030 & 0.327 & 0.153 & 0.372 & 0.008 & 6.903 & 0.855 & 0.951 & 1.432 & 0.234 & 0.124 & 0.028 \\
\hline 3761.5 & 1.519 & 6.790 & 3.627 & 4.197 & 2.881 & 89.103 & 0.107 & 0.477 & 0.255 & 0.295 & 0.202 & 6.258 & 1.253 & 2.634 & 3.251 & 0.174 & 0.090 & 0.037 \\
\hline 3762.5 & 0.526 & 4.263 & 0.526 & 3.263 & 1.264 & 90.158 & 0.037 & 0.298 & 0.037 & 0.228 & 0.088 & 6.311 & 1.723 & 3.264 & 1.234 & 0.136 & 0.080 & 0.070 \\
\hline 3709.8 & 78.320 & 8.435 & 4.324 & 4.253 & 2.153 & 2.515 & 17.230 & 1.856 & 0.951 & 0.936 & 0.474 & 0.553 & 57.234 & 6.435 & 3.222 & 1.264 & 0.020 & 0.043 \\
\hline 3710 & 76.620 & 8.453 & 4.263 & 5.060 & 2.040 & 3.564 & 13.792 & 1.522 & 0.767 & 0.911 & 0.367 & 0.642 & 63.523 & 7.435 & 1.533 & 1.226 & 0.010 & 0.012 \\
\hline 3642.2 & 72.312 & $\begin{array}{l}.45034 \\
16.345\end{array}$ & 2.643 & 5.423 & 2.230 & 1.047 & 10.847 & 2.452 & 0.396 & 0.813 & 0.335 & 0.157 & 79.435 & 5.435 & 3.954 & 0.643 & 0.030 & 0.034 \\
\hline 3644.2 & 70.345 & 15.263 & 3.725 & 5.123 & 2.150 & 3.394 & 11.396 & 2.473 & 0.603 & 0.830 & 0.348 & 0.550 & 77.435 & 6.723 & 3.523 & 0.964 & 0.020 & 0.026 \\
\hline 3643.2 & 72.345 & 15.243 & 3.254 & 5.769 & 2.384 & 0.320 & 14.572 & 3.070 & 0.655 & $\begin{array}{l}.030 \\
1.620\end{array}$ & 0.194 & 0.026 & 69.325 & 4.724 & 3.990 & 0.536 & 0.030 & 0.010 \\
\hline 3907.4 & 76.324 & 10.320 & 5.230 & 5.120 & 2.140 & 0.850 & 15.373 & 2.079 & 1.053 & 1.031 & 0.431 & 0.171 & 80.364 & 9.435 & 2.534 & 1.383 & 0.010 & 0.016 \\
\hline
\end{tabular}




\subsection{Diagenesis Type}

The sandstone reservoir densification of the Toutunhe Formation in the Kayindike area is attributed to the high matrix content and severe carbonate cementation (densification does not happen to the WDF), as revealed via the analysis of petrology, reservoir space, and physical property of the sandstone reservoir.

\subsubsection{Compaction}

Compaction is the uppermost diagenetic factor damaging the Toutunhe sandstone reservoir, as demonstrated by the apparent negative correlation between the burial depth and sandstone physical properties in well Y1 (Figure 5). The high matrix content is an important reason for severe mechanical compaction. Under compaction, the matrix was squeezed into small pores and throats, which led to extensive plugging of primary pores and tremendous degradation of permeability [47]. Meanwhile, ductile particles form a large number of pseudo-matrices during compaction associated with meteoric water leaching, which further promoted the compaction-induced damage to the reservoir [47]. The primary porosity was computed empirically using the sorting coefficient that was obtained from the grain size analysis. Subsequently, the porosity loss due to compaction was then calculated using the compaction coefficient. The results show that the compaction-induced porosity loss was about $2 \%$ to $62.5 \%$ for the Toutunhe sandstone in the Kayindike area (Figure 3b).

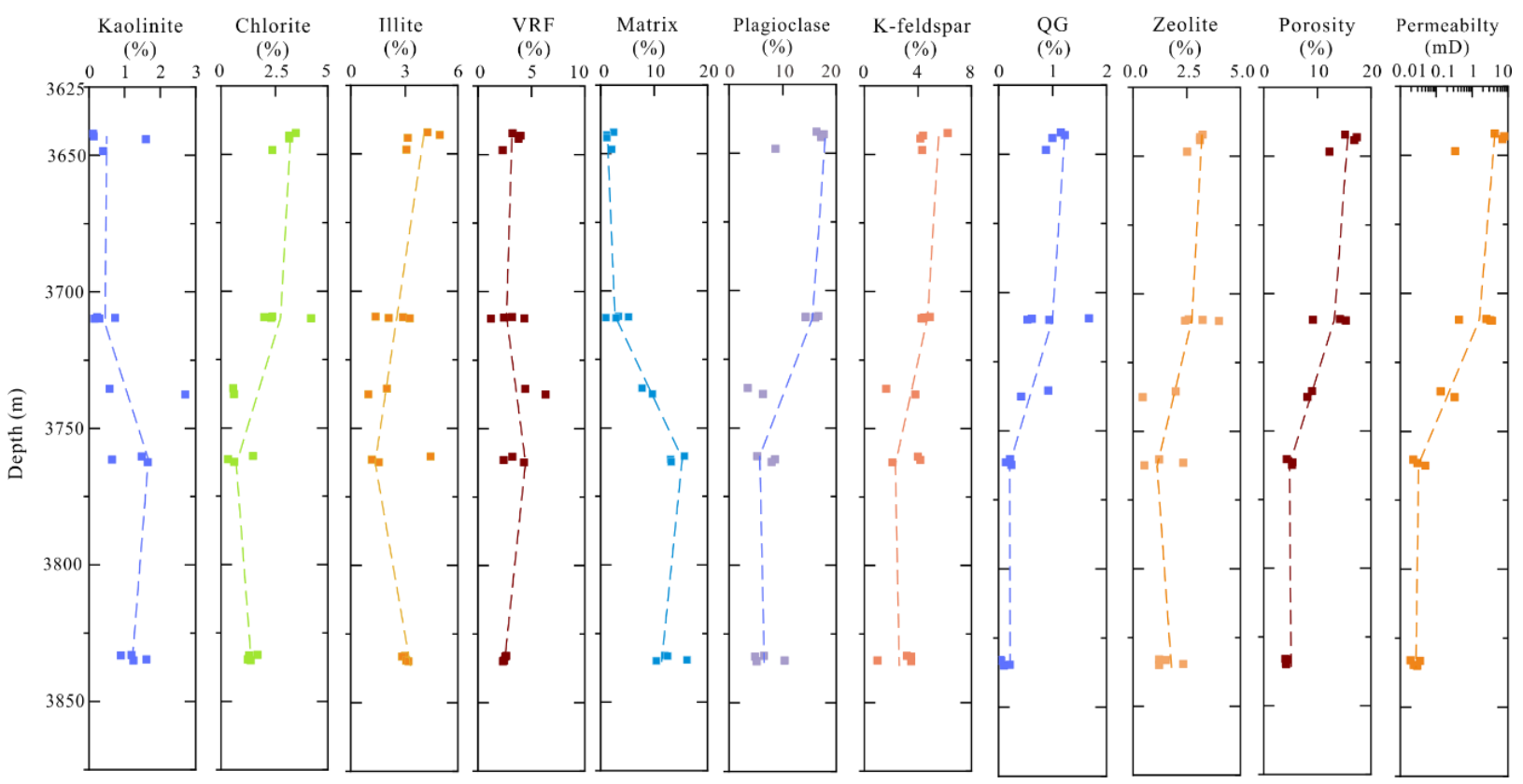

Figure 5. The vertical distribution of mineral composition and petrophysical property in the Toutunhe Formation sandstone. VRF: volcanic rock fragment; QG: quartz overgrowth.

\subsubsection{Cementation}

The cementation degree of the Toutunhe sandstone reservoir in the Kayindike area is low. Eodiagenesis was dominated by calcite cementation, analcite cementation, and filming of authigenic clay minerals. In contrast, mesodiagenesis manifested itself mainly in the extensive conversion of smectite into chlorite and illite, accompanied by cementation of ferrocalcite, laumontite, halite, anhydrite, and ferrodolomite.

There are various types of authigenic clay minerals in the Toutunhe sandstone reservoir, yet with limited contents (Figure 5, Table 1). SEM images of samples from Wells Y1, $\mathrm{Y} 2$, and $\mathrm{Y} 3$ all show clay minerals of numerous morphologies, which are mainly illite and chlorite. However, due to their low overall content, clay minerals have smaller effects on the reservoir's physical property. Illite, observed in bridge-like, fibrous, and sheet-like shapes, mostly fills the residual inter-granular and inter-granular pores, with an average 
content of $2.68 \%$. A positive correlation is found between the content of illite and chlorite, which suggests a possible genesis of illite from smectite conversion that usually produced sheet-like illite [48]. Figure 5 implies that most illite may came from kaolinite conversion, which required temperatures of $120{ }^{\circ} \mathrm{C}$ to $130{ }^{\circ} \mathrm{C}$ and often generated bridge-like and fibrous illite. To sum up, the main contributors to the illite in the Toutunhe sandstone are kaolinite and smectite conversion, and illite has limited effects on the sandstone's physical property, due to its low content (Figure 5, [48]).

The chlorite in the Toutunhe tight sandstone mostly occurs as the cover film or lining. Extensive development of flaky chlorite films is observed, of which the genesis was often controlled by the sedimentary environment-most of such chlorite was converted from iron-containing leading minerals (such as berthierine and biotite; [2]). Moreover, the strong positive correlation between the illite and chlorite contents shows that smectite conversion is also an important source of chlorite, which was often associated with occurrences of authigenic illite (Figure 5, [48,49]). Magmatic rock fragments were in most cases chemically active and hence were prone to montmorillonitization and chloritization [2]. The authigenic chlorite may be related to the dissolution of magmatic rock fragments, as inferred by the negative correlation between the chlorite and magmatic rock fragment content (Figure 5). In addition, the high-content matrix tended to occupy the space where the film of flaky chlorite developed and consequently suppressed the growth of chlorite. The porosity and permeability are found to be positively correlated with the chlorite content (Figure 5), which can be explained by the fact that the chlorite film preserved the primary pore by taking up the space for quartz nucleation and also to some extent increased the compaction resistance of sandstone [12,50,51].

Due to the dry and hot climate, the Toutunhe tight sandstone is associated with a low content of kaolinite, which is mainly book-like (blocky kaolinite is less observed) and filled residual inter-granular pores (Figure 4l). The kaolinite content is highly negatively correlated with the feldspar content, which implied the main source of kaolinite was eogenetic feldspar dissolution. The hydrocarbon expulsion occurred relatively late, and the organic acid content in the non-coal-bearing formations was low. Therefore, the acid fluid dissolving feldspar was mostly meteoric water [52]. Nevertheless, it should be noted that the kaolinite content of the Toutunhe tight sandstone was further reduced, as most kaolinite is transformed into illite at a temperature over $120^{\circ} \mathrm{C}[53,54]$. Kaolinite was destructive to the reservoir's physical property, as suggested by its negative correlation with porosity and permeability (Figure 5).

The carbonate cement in the Toutunhe Formation includes calcite, ferrocalcite, and ferrodolomite, generally developing at the base of the braided river channel. There are two stages of calcite cementation - the eogenetic basal cementation of calcite mostly filled the inter-granular pore (Figure $4 \mathrm{~d}, \mathrm{e}$ ), while the mesogenetic patchy ferrocalcite often replaced rock fragments and feldspar (Figure $4 \mathrm{f}, \mathrm{g}$ ). The cementation temperatures of calcite of the two stages were calculated according to the carbon and oxygen isotope ratios [45]. It is found that the genesis of the eogenetic sparry calcite was mainly meteoric water leaching, with the cementation temperature at $31.67{ }^{\circ} \mathrm{C}$ to $54.82{ }^{\circ} \mathrm{C}$. Moreover, $\mathrm{Ca}^{2+}$ in the sparry calcite cement mostly derived from the mudstone interbedded in the thick sandstone and also mudstone adjacent to the sand body (Figure 6). This means that the diagenetic environment for the eogenetic calcite cementation was open and thus it was highly influenced by meteoric water leaching and mudstone near the sandstone (Figure 6). The mesogenetic patchy ferrocalcite developed at the cementation temperature of $96{ }^{\circ} \mathrm{C}$ to $120^{\circ} \mathrm{C}$, typically after intensive compaction. Its genesis was primarily related to the decarboxylation of organic acid (Figure 6), which was supported by the closeness between the cementation time of ferrocalcite and ferrodolomite and hydrocarbon emplacement. No considerable correlation with the distance to mudstone was identified for the ferrocalcite content. Therefore, the mudstone near the sandstone was not the main material source for ferrocalcite, which suggested that the diagenetic environment at the time was more sealed and the ions of ferrocalcite were sourced internally from the sandstone (Figure 6). 


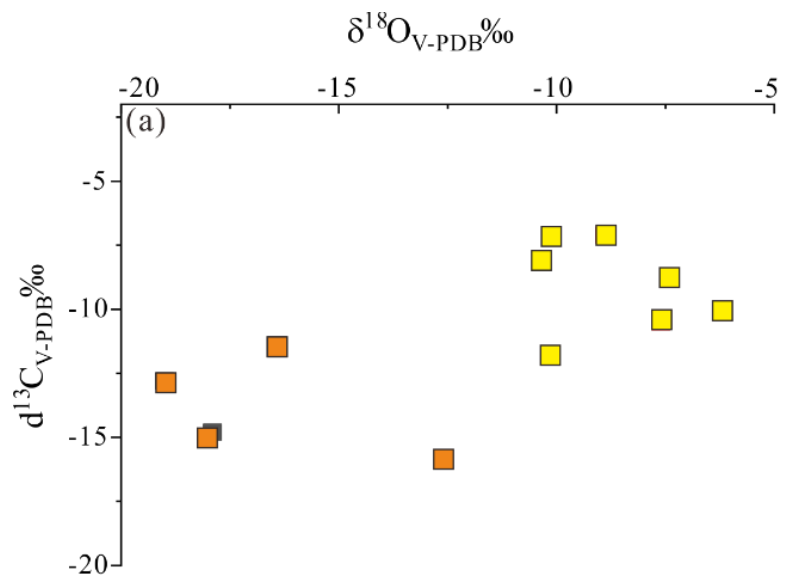

Samples with high content of ferrocalcite

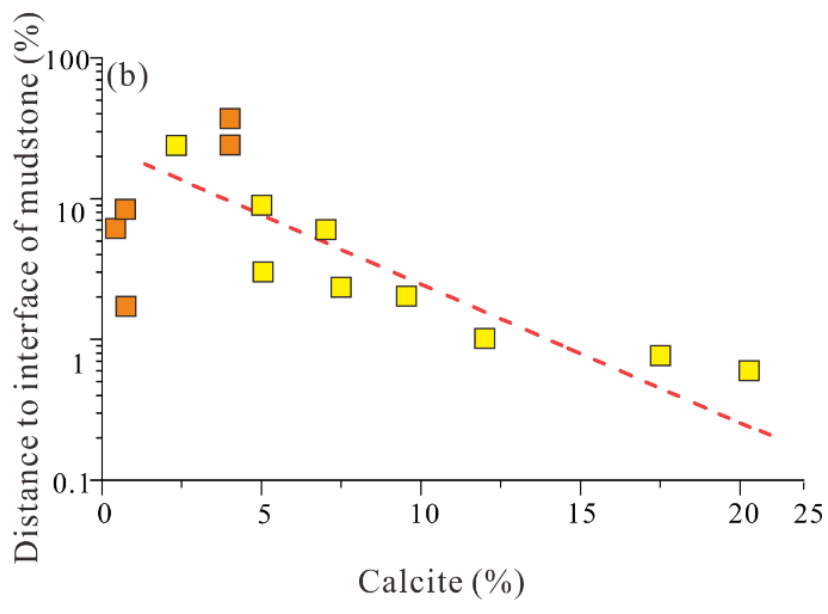

Samples with high content of poikilitic calcite

Figure 6. Features of carbon-oxygen stable isotopes for carbonate cements (a) and the relationship between the carbonate cement and the distance to mudstone/sandstone interface in Toutunhe formation sandstones (b).

Quartz cementation in the Toutunhe tight sandstone of the Kayindike area was mainly embodied as secondary overgrowth of quartz, and in a few cases, authigenic quartz microlite adhered to particle surfaces or filling pores. Quartz cement of the Toutunhe sandstone was associated with the low overall content and yet wide distribution. The content of quartz overgrowth has a high positive correlation with the detrital quartz content, which proved pressure solution as one of the major sources of silicon ions. The process of converting smectite into illite also produced authigenic quartz (Figure 5). The electron probe data reveals high contents of aluminum and iron ions in the quartz secondary overgrowth, which confirmed that the conversion of smectite into illite provided $\mathrm{Si}^{4+}$ for quartz overgrowth (Figure 7a,b). Dissolution of plagioclase could generate illite and authigenic quartz, which was supported by both the positive correlation between the contents of plagioclase, illite, quartz overgrowth, and the quartz overgrowth with a higher content of sodium ions identified by the electron probe (Figure 7c,d). In addition, the high-content matrix may have occupied the nucleation position of quartz overgrowth and thus reduced the content of the latter (Figure 5). The development of quartz overgrowth also had two stages, as indicated by the measured homogenization temperatures of the brine inclusions in the quartz overgrowth. The corresponding cementation temperatures were $70{ }^{\circ} \mathrm{C}$ to $75{ }^{\circ} \mathrm{C}$ and $105^{\circ} \mathrm{C}$ to $130{ }^{\circ} \mathrm{C}$ (Figure 8 ; [55]). Since smectite often transforms into illite at around $70^{\circ} \mathrm{C}$, the 1st stage of quartz cementation was likely to be related to smectite illitization. For the stage at $105^{\circ} \mathrm{C}$ to $130{ }^{\circ} \mathrm{C}$, the silicon ion might be sourced from the pressure solution of detrital quartz and the dissolution of plagioclase (Figure 8; [55]). The quartz overgrowth content is positively correlated to both porosity and permeability of the Toutunhe tight sandstone, which implies it to some extent promoted the compaction resistance of the reservoir and protected primary inter-granular pores (Figure 5). 

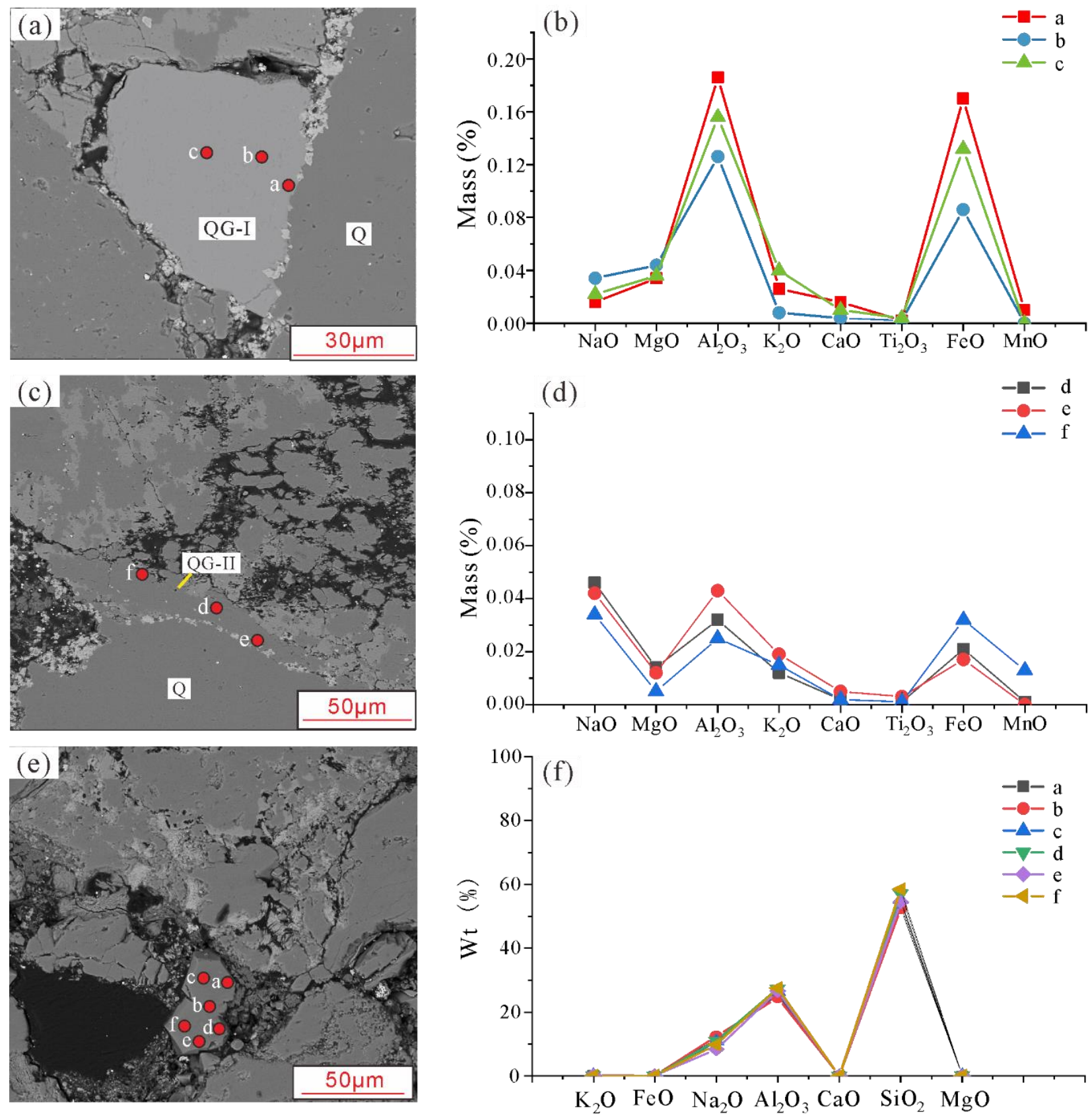

Figure 7. In situ microprobe analysis for quartz and zeolite in the Toutunhe Formation sandstone. (a) Backscattered electron image exhibiting experimental point situations of quartz for the sample $3643.2 \mathrm{~m}$, well X1; (b) elemental composition distribution features of a quartz grain in sample $3643.2 \mathrm{~m}$, well X1; (c) backscattered electron image exhibiting experimental point situations of quartz for the sample $3907.4 \mathrm{~m}$, well X1; (d) elemental composition distribution characteristics of a quartz grain in sample $3907.4 \mathrm{~m}$, well X1; (e) backscattered electron image exhibiting experimental point situations of zeolite for the sample $3710 \mathrm{~m}$, well X1; (f) elemental composition distribution features of a zeolite grain in sample $3710 \mathrm{~m}$, well X1. 

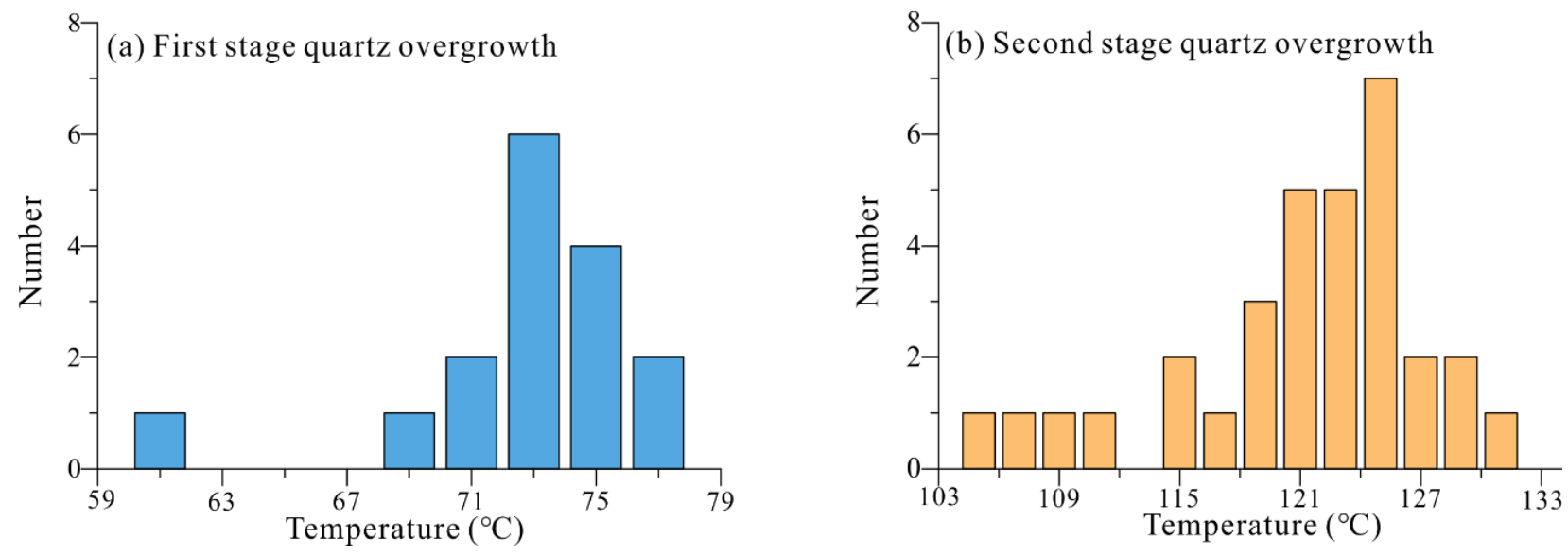

Figure 8. Frequency histogram of homogenization temperature from inclusions in authigenic quartz cements of the Toutunhe Formation sandstone. (a) Homogenization temperature of the first stage quartz overgrowth; (b) homogenization temperature of the second stage quartz overgrowth.

Zeolite cementation mainly involved analcite and laumonite (Figure 9), with a few mordenite and clinoptilolite. The zeolite content in the Toutunhe Formation is considerably higher than that for other layers (Figure 9). Analcite often occurred in the form of basal and interstitial cementation and is considered the sedimentary type. The analcite in the form of the tetrahedral trioctahedron was typically concentrated near the magmatic rock fragment and feldspar (Figure 9f; [56]). The analcite content is negatively correlated with the volcanic rock fragment, which infers that the eogenetic analcite might be linked to the syndepositional volcanic activity during the Late Jurassic (Figure 5).

Dissolution and decomposition of massive volcanic rock fragments and tuff often resulted in an alkaline diagenetic environment, which happened to be the most favorable for analcite formation. The eogenetic dissolution products of volcanic rock fragments could serve as the source of leading minerals of zeolite, e.g., mordenite, clinoptilolite, and kaolinite (Figure 9; [12]). These leading minerals were converted into analcite at the burial temperature over $20^{\circ} \mathrm{C}$ to $120^{\circ} \mathrm{C}$ [57-59]. The analcite in the Toutunhe Formation is featured by an $\mathrm{Si} / \mathrm{Al}$ ratio range of $2.32-2.48$, a high $\mathrm{Na}$ content, and rare $\mathrm{K}$ (Figure 7e-f). Thus, it was safe to say that the analcite of basal cementation might be eogenetic, with the genesis attributed to felsic volcanic glass. Such analcite often presented certain thermal stability [56].

In the mesogenetic stage, the diagenetic environment again became alkaline-the solubility of silicon dioxide was reduced and the chemical stability of albite and kaolinite degraded [56], which provided sodium, silicon, and aluminum ions for analcite [58].

As the silicon ion activity to some extent controlled stabilization of analcite, analcite often coexists with quartz microlite. Besides, the zeolite content is in direct proportion to the illite content, which implies that the smectite illitization that released sodium and silicon ions helped to form analcite (Figure 5).

The diagenetic analcite enhanced the compaction resistance of sandstone, although it occupied some pore space. This was critical to the Toutunhe sandstone- - the limited content of eogenetic analcite cementation played a vital role in easing mechanical compaction. In addition, many scholars claimed that zeolite was highly prone to dissolution, which could significantly improve the reservoir's physical property (Figure 5). However, the dissolution modification in the Toutunhe sandstone was relatively weak [60], and the porosity gain attributed to zeolite dissolution pores was less than $0.5 \%$. 


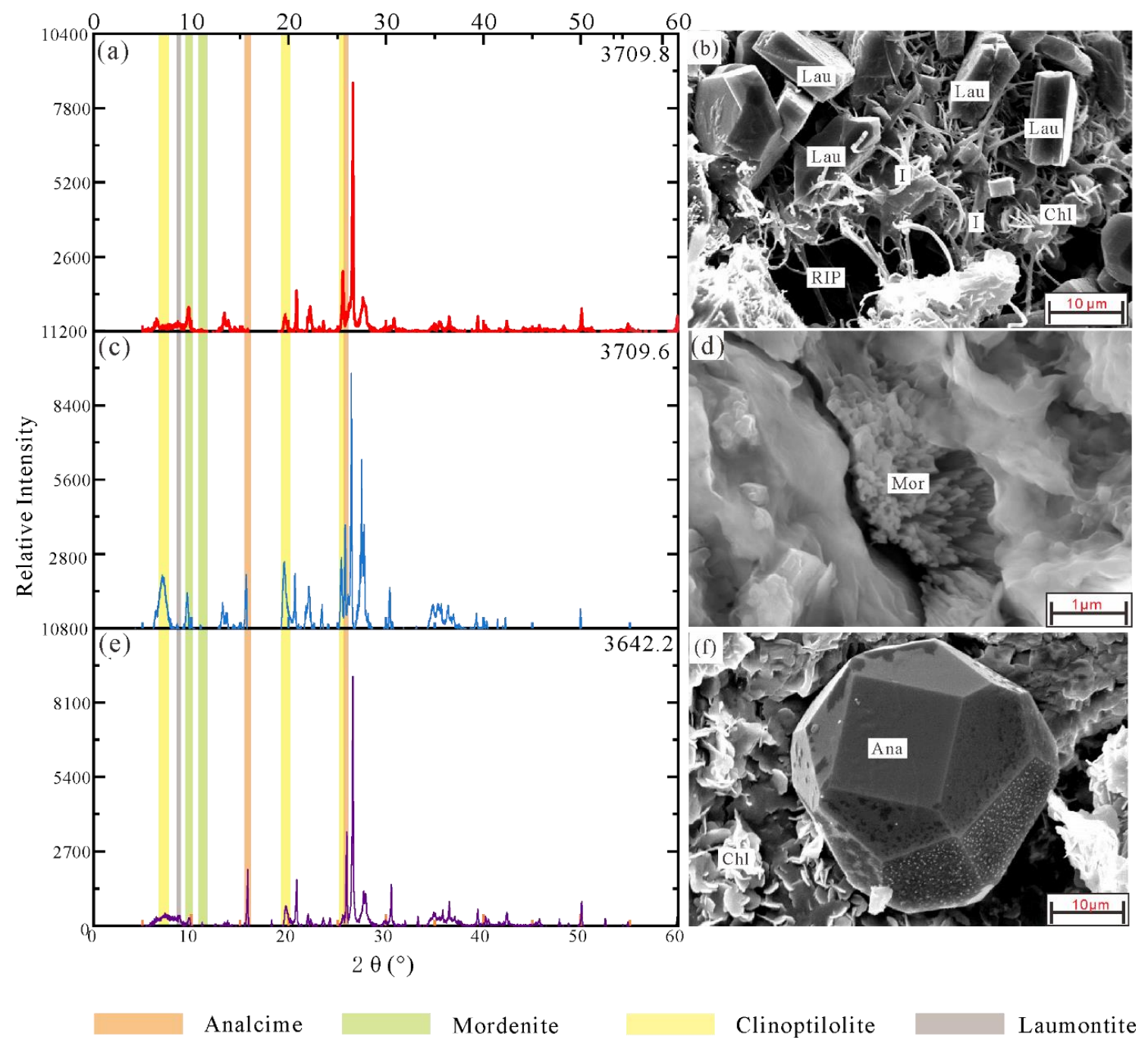

Figure 9. XRD patterns and micrographs of representative samples with various kinds of zeolite in the Toutunhe Formation sandstone reservoir. (a) XRD pattern of sample $3709.8 \mathrm{~m}$, whole-rock analysis, X1 well; (b) columnar laumontite widely dispersed in residual intergranular pores, $3709.8 \mathrm{~m}$, X1 well; (c) XRD pattern of sample, $3709.6 \mathrm{~m}$, whole-rock analysis, X1 well; (d) fibrous mordenite developed in the residual intergranular pores, $3709.6 \mathrm{~m}$, X1 well; (e) XRD pattern of sample $3643.2 \mathrm{~m}$, whole-rock analysis, X1 well; (f) euhedral analcime crystal developed on the detrital quartz grain, $3643.2 \mathrm{~m}$, X1 well.

\subsubsection{Dissolution}

Dissolution was commonly weak in the Toutunhe Formation reservoir of the Kayindike area, which was mainly manifested as the feldspar dissolution and selective dissolution of lithic particles, with a few cases of cement dissolution such as calcite and analcite. SEM and pore-casted thin section observations revealed that the mineral edge was often associated with small-scale dissolution and the overall porosity gain by dissolution is less than $5 \%$ on average. Hence, it was concluded that dissolution had minor contributions to the storage capacity of the Toutunhe reservoir.

\subsection{Hydrocarbon Charging Periods}

According to the petrographic analysis, homogenization temperature measurement, and fluorescence spectral test of the 136 fluid inclusions of 16 Toutunhe Formation sandstone samples collected from Well Y1 in the Kayindike area, the reservoir should have been subjected to only one stage of hydrocarbon emplacement (Figure 10). The resultant fluid inclusion was generally found with yellow-yellow white fluorescence. It typically occurred in quartz fractures and secondary fractures in the linear and separated forms, with 
low gas-liquid ratios. The homogenization temperature of these yellow while fluorescent fluid inclusions is $100{ }^{\circ} \mathrm{C}$ to $115^{\circ} \mathrm{C}$, and the maximum wavelength ranges from $525 \mu \mathrm{m}$ to $540 \mu \mathrm{m}$. In accordance with the burial depth, such oil inclusions were trapped during 13 to $8 \mathrm{Ma}$. The massive hydrocarbon generation of the Lower Jurassic source rock in the Kayindike area occurred at about $12 \mathrm{Ma}$ [61], and the vitrinite reflectance (Ro) of the Badaowan Formation source rock ranging from $0.6 \%$ to $0.7 \%$, just reached the hydrocarbon expulsion threshold (about 0.6) at 10 Ma [62]. Given the oil-source correlation resulted for the Kayindike area by other researchers, it was believed that the hydrocarbons of the Toutunhe Formation were mainly sourced from the low-maturity source rock of the Jurassic Badaowan Formation [63].
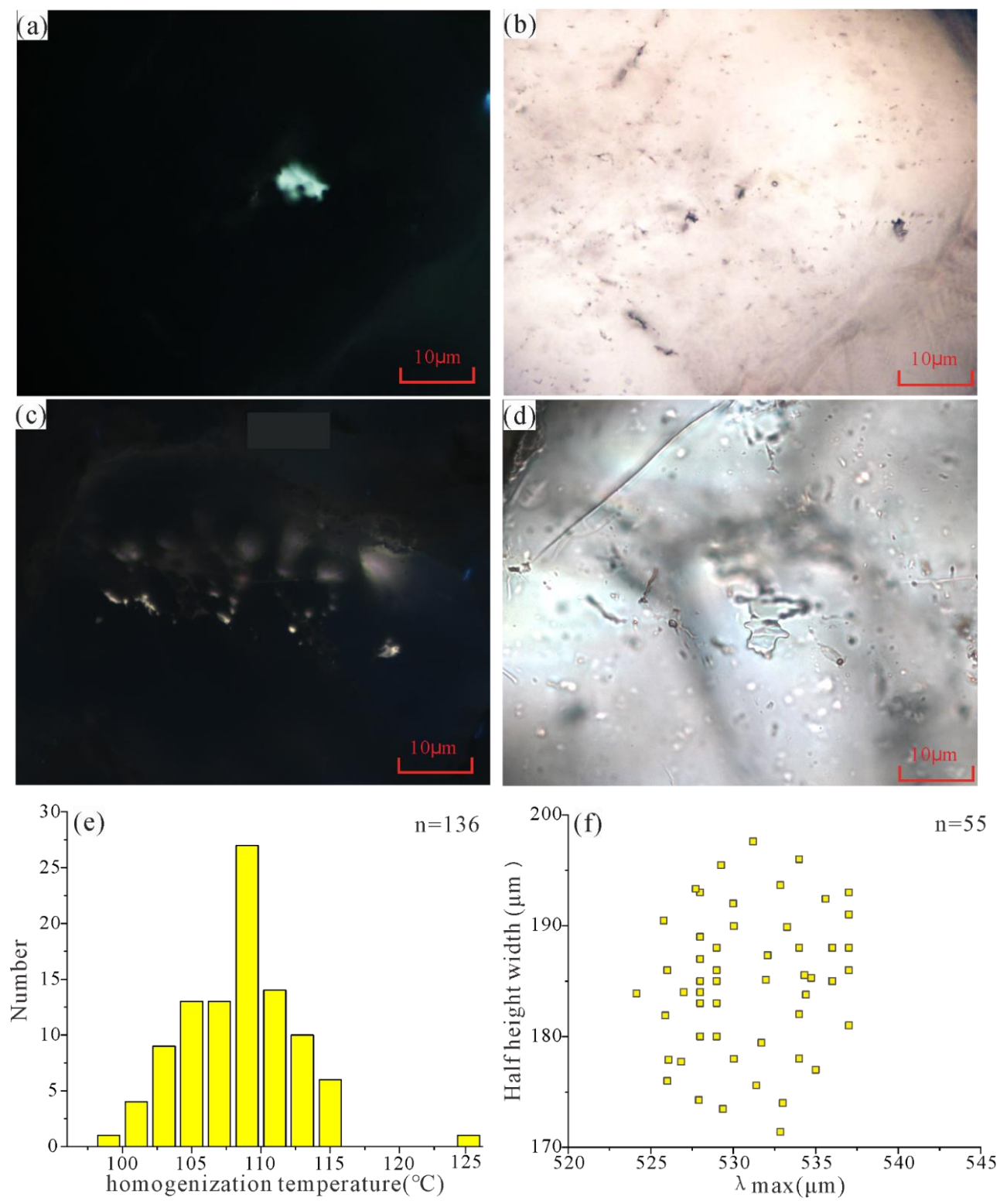

Figure 10. Micrographs of oil inclusions of the sandstone reservoirs in the Toutunhe Formation. Yellow fluorescent oil inclusions trapped in a quartz crack, (a) transmission light and (b) fluorescent light, $3709.4 \mathrm{~m}$, Y1 well; yellow fluorescent oil inclusions trapped in healed microfractures developed in a detrital quartz grain, (c) transmission light and (d) fluorescent light, $3642.2 \mathrm{~m}$, Y1 well; histogram of homogenization temperatures of aqueous inclusions corresponding to oil inclusions in the same oil-aqueous inclusion pairs (e); Scatter of half height width and $\lambda_{\max }$ of fluorescence in oil inclusion (f). 


\section{Discussion}

After clarifying the diagenetic process of the Toutunhe sandstone in the Kayindike area, an attempt is made to discuss the reservoir formation mechanism of the Toutunhe sandstone, by integrating the hydrocarbon emplacement time, diagenetic sequence, and sandstone reservoir wettability, also in accordance with the burial process and tectonic movement.

\subsection{Relationship between Hydrocarbon Emplacement and Sandstone Reservoir Densification}

Here in this section, we discussed the temporal sequence of sandstone densification and hydrocarbon emplacement, based on the identified hydrocarbon emplacement time and the above analysis of the main diagenetic events and their mechanisms of the Toutunhe tight sandstone.

\subsubsection{Diagenetic Sequence}

The diagenetic process of the Jurassic Toutunhe Formation sandstone reservoir in the Kayindike area mainly included compaction, cementation, dissolution, and metasomatism. The diagenetic stage was the mesogenetic A stage (Figure 11). During the early deposition, the Toutunhe sandstone at the base of the braided river channel featured a high content of matrix, while the sandstone at the center of the braided river channel and that in the shore-lake environment was characterized by high porosity and high permeability. Due to the syndepositional volcanic materials, the diagenetic environment during the eogenetic A stage was alkaline, in which the tuffaceous rock fragments related to the Late Jurassic syndepositional volcanic activities and other magmatic rock fragments started to transform into the iron-containing leading minerals that were subsequently converted into the flaky chlorite film, analcite, and smectite. Afterward, with meteoric water leaching, the cementation of sparry calcite initiated at $31^{\circ} \mathrm{C}$ to $54{ }^{\circ} \mathrm{C}$. At this time, the burial rate was rather small, and the mechanical compaction slowly proceeded.

Later, the diagenetic environment gradually became acid, in which small-scale dissolution occurred in feldspar and rock fragments. Also, the diagenetic environment was transformed from an open state to a closed state, and blocky cementation of kaolinite occurred. Sediment started to endure rapid burial, as the formation temperature reached $65{ }^{\circ} \mathrm{C}$. The main compaction process changed from mechanical compaction into chemical pressure solution. When the formation temperature reached $70^{\circ} \mathrm{C}$, smectite started to transform into illite, associated with the generation of secondary quartz overgrowth and microlite. Upon the arrival of the mesogenetic A stage, the formation temperature exceeded $90{ }^{\circ} \mathrm{C}$. At this time, some kaolinite started to change into illite or analcite; the main shapes of illite transformed from sheet-like into bridge-like or fibrous; pompon-and rosette-like chlorite occurs. Meanwhile, smectite illitization offered a massive number of sodium, aluminum, and silicon ions, which stimulated the formation of analcite. With the sustained growth of the burial depth, the formation temperature rose to $100-115^{\circ} \mathrm{C}$ and the second stage of quartz cementation occurred. In the meantime, the hydrocarbon expulsion of the Badaowan source rock began and so did the decarboxylation process of organic matter-the carbonate ion content of the pore water sharply increased, and these carbonate ions bind with the magnesium, calcium, and iron ions, released by dissolution and clay mineral conversion, to form ferrocalcite and ferrodolomite. When the diagenetic environment turned to calcium-alkaline, analcite started to transform into laumontite.

\subsubsection{Porosity Evolution}

The pore evolution models of the CCF, the MTCF, and the WDF was developed in this research via the pore evolution reconstruction method proposed by Dou ([64]; Figure 11). The pore evolution process was described in detail in Table 3. The carbonate cemented facies was mainly characterized by the relatively high content of calcite, ferrocalcite, ferrodolomite, and matrix. For example, Sample 3809.8 had original porosity of $38 \%$, which was subjected to compaction-caused loss of $18.1 \%$. The eogenetic calcite cementation led to the most porosity reduction, while it to some extent enhanced the compaction resistance 
of the sandstone reservoir, which resulted in the compaction-related porosity loss smaller than that of the MTCF. The mesogenetic ferrocalcite and ferrodolomite cementation led to porosity loss of about $4 \%$, and the porosity of the carbonate cemented facies had dropped to $10 \%$ since $9 \mathrm{Ma}$, which represented densification of the sandstone reservoir (Table 3).

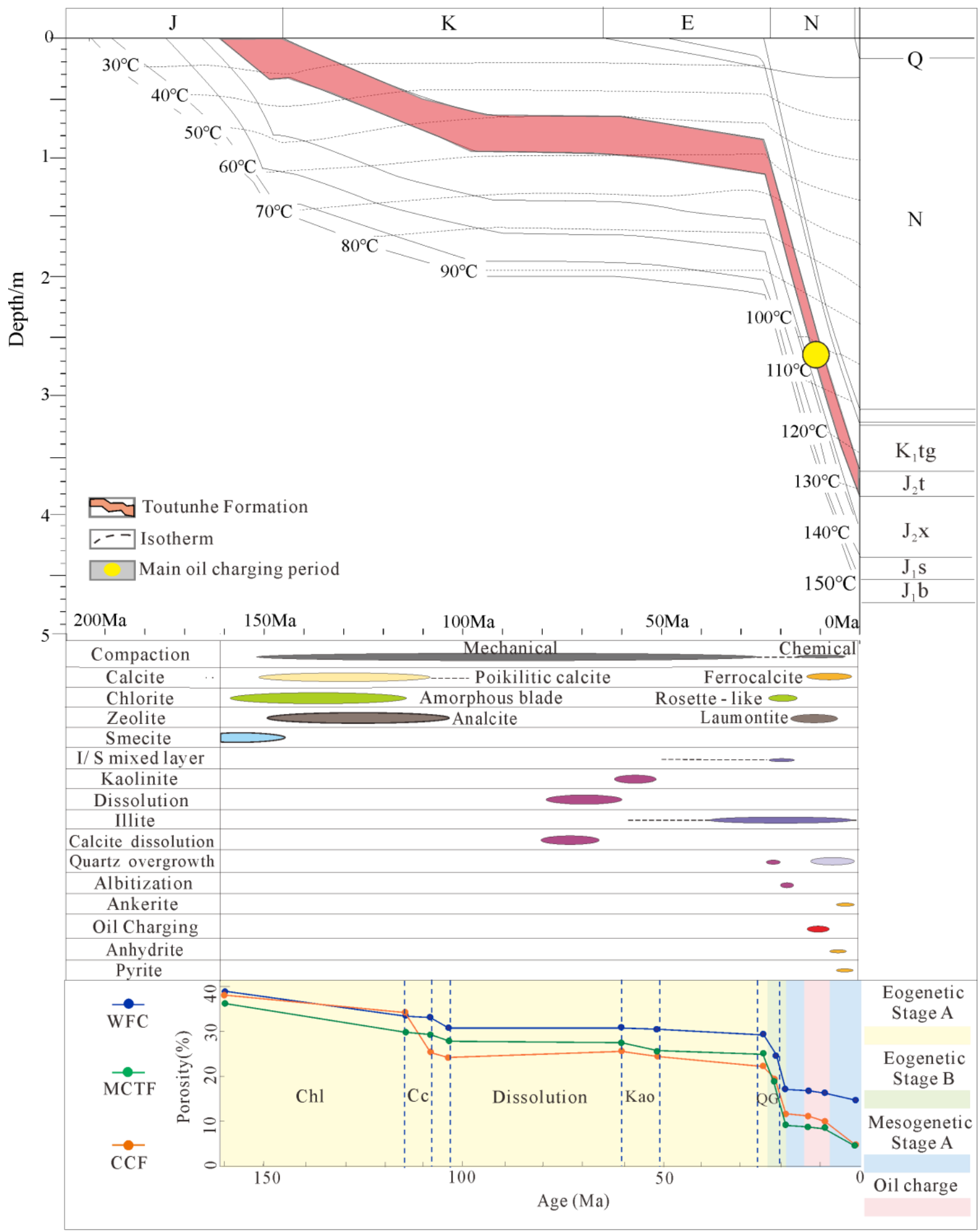

Figure 11. Diagenesis sequence and hydrocarbon charging timing of three lithofacies in the Toutunhe Formation. J: Jurassic, K: Cretaceous, E: Paleogene, N: Neogene, $\mathrm{K}_{1} \mathrm{tg}$ : Tugulu Formation, $\mathrm{J}_{2} \mathrm{t}$ : Toutunhe Formation, $\mathrm{J}_{2} \mathrm{x}$ : Xishanyao Formation, $\mathrm{J}_{1} \mathrm{~s}$ : Sangonghe Formation, $\mathrm{J}_{1}$ b: Badaowan Formation. Chl: chlorite, Cc: calcite, Kao: kaolinite, QO: quartz overgrowth. 
Table 3. The fraction proportion and porosity of different pore types in representative samples of the Toutunhe Formation.

\begin{tabular}{|c|c|c|c|c|c|c|c|c|c|c|c|c|c|c|c|c|c|c|}
\hline \multirow{2}{*}{$\begin{array}{c}\text { Repres- } \\
\text { entative } \\
\text { Sam- } \\
\text { ples }\end{array}$} & \multirow{2}{*}{$\begin{array}{l}\text { of Litho- } \\
\text { facies }\end{array}$} & \multirow[b]{2}{*}{$\begin{array}{l}\text { OP } \\
(\%)\end{array}$} & \multicolumn{6}{|c|}{ Eogenetic Stage } & \multicolumn{7}{|c|}{ Mesogenetic Stage } & \multirow[b]{2}{*}{$\begin{array}{l}\text { COPL } \\
(\%)\end{array}$} & \multirow{2}{*}{$\begin{array}{l}\text { Calculated } \\
\text { Porosity } \\
\quad(\%)\end{array}$} & \multirow{2}{*}{$\begin{array}{c}\text { Helium } \\
\text { Porosity } \\
(\%)\end{array}$} \\
\hline & & & $\begin{array}{l}\text { CLPL } \\
(\%)\end{array}$ & $\begin{array}{l}\text { CCPL } \\
(\%)\end{array}$ & $\begin{array}{l}\text { ZEOPL } \\
(\%)\end{array}$ & $\begin{array}{c}\text { DP } \\
(\%)\end{array}$ & $\begin{array}{l}\text { KAOPL } \\
(\%)\end{array}$ & $\underset{(\%)}{\text { QGPL }}$ & $\begin{array}{l}\text { CLPL } \\
(\%)\end{array}$ & $\underset{(\%)}{\text { ZEOPL }}$ & $\underset{(\%)}{\text { QGPL }}$ & $\begin{array}{c}\text { ILLPL } \\
(\%)\end{array}$ & $\begin{array}{l}\text { CCPL } \\
(\%)\end{array}$ & $\begin{array}{l}\text { DOLPL } \\
(\%)\end{array}$ & $\begin{array}{l}\text { SIDPL } \\
(\%)\end{array}$ & & & \\
\hline 3760.3 & TCF & 35.23 & 1.18 & 0.00 & 1.00 & 0.46 & 1.49 & 0.05 & 0.31 & 0.23 & 0.17 & 4.47 & 0.00 & 0.00 & 0.00 & & & 4.33 \\
\hline 3809.8 & CCF & 38.00 & 0.00 & 8.74 & 0.70 & 2.24 & 0.90 & 0.05 & 0.02 & 0.34 & 0.00 & 2.89 & 2.00 & 2.00 & 0.00 & 18.10 & 4.50 & 4.43 \\
\hline 3709.4 & WDF & 39.00 & 2.00 & 0.00 & 2.20 & 0.89 & 0.23 & 1.24 & 0.40 & 0.40 & 0.44 & 1.40 & 0.00 & 0.00 & 0.34 & 17.03 & 14.55 & 14.25 \\
\hline
\end{tabular}

CCF: carbonate cemented facies, MTCF: matrix-caused tightly compacted facies; WDF: weakly diagenetic reformed facies; OP: original porosity; CLPL: chlorite cementation porosity loss; ZEOPL: zeolite porosity loss; CCPL: carbonate cementation porosity loss; KAOPL: kaolinite cementation porosity loss; ILLPL: illite cementation porosity loss; COPL: compactional porosity loss; OGPL: quartz overgrowth porosity loss; DP: dissolution porosity; DOLPL: dolomite cementation porosity loss; SIDPL: siderite cementation porosity los.

The MTCF was generally associated with a higher matrix content. Taking Sample 3645.3 as an example, its matrix content was high, up to $15.74 \%$ (Table 3). This resulted in the phenomenon that the original porosity of this facies was smaller than that of the other two facies. Mechanical compaction was the uppermost contributor to porosity reduction of this facies, and the corresponding porosity reduction could be up to $22.46 \%$. In addition, the high-content authigenic clay mineral aggravates damage to the tight sandstone caused by compaction and also further plugged the reservoir space, especially for fibrous illite. The porosity of the MTCF declined to $10 \%$ since $18 \mathrm{Ma}$ and became densified.

As for the WDF, it features "weak cementation", "weak compaction", and "weak dissolution". Its compaction-induced porosity reduction was smaller than that of both the carbonate-cemented and MTCF. For instance, Sample 3907.4 presented a porosity loss related to compaction by $17.33 \%$. Since the sandstone commonly had coarser rock particles and well-developed chlorite film, the preservation condition for the residual inter-granular pore was rather good in the WDF. Therefore, the sandstone reservoir of this facies had not been through densification.

\subsubsection{Reservoir-Forming Mechanism}

The primary porosity of the three facies of the Toutunhe Formation sandstone in the Kayindike area was distinctly different (Figure 12). Due to the higher content of the matrix, the MTCF had the least primary porosity, while the WDF had the best primary physical properties, due to its higher sandstone maturity (Table 3). From the Late Jurassic to Early Cretaceous, due to the tectonic movement, the northern part of the Kayindike area was subjected to tectonic compression and a series of EW-striking anticlines occurred-the Kayindike anticline was formed. In the meantime, a series of EW-trending faults were also created and referred to as the Aika fault belt [65], which connected the Mid-Lower Jurassic source rock and the Toutunhe Formation reservoir (Figure 12).

The burial rate during the eodiagenesis was relatively slow and mechanical compaction had lower destructive effects on the reservoir quality. The volcanic materials derived from syndepositional volcanism were converted into flaky chlorite film. The mineral particle surface of the WDF was easier to form chlorite films and analcite cementation, due to the lower matrix content, and such cement could help to preserve the primary pores, yet with the inevitable resultant porosity reduction of $0.7 \%$ to $4.2 \%$. The other facies were found with fewer chlorite films and analcite cementation. As located in the margin of the braided river channel, the carbonate-cemented facies was more prone to mudstone in the floodplain. Sparry calcite cementation occurred between $152 \mathrm{Ma}$ and $182 \mathrm{Ma}$. This extensively plugged inter-granular pores, resulting in great porosity reduction up to $7 \%$ to $12 \%$, although it also to some extent relieved damage to the reservoir physical property due to mechanical compaction. Dissolution of framework particles started at $78 \mathrm{Ma}$, owing to meteoric water leaching, and authigenic minerals such as kaolinite and smectite-illite mixed layers and quartz secondary overgrowth were generated. Nonetheless, the dissolution modification was found with very limited effects and the average porosity increment was only around $1.19 \%$. From the end of the Paleogene to the end of the Shawan period, the Sikeshu Sag was again subjected to the tectonic stress of northward compression. The Toutunhe Formation rapidly subsided and the mechanical compaction effect was greatly intensified. The MTCF had passed the densification limit since $18 \mathrm{Ma}$, upon which the compaction was dominated by pressure solution; the 2nd stage of 
quartz cementation occurred, with the coexistence of illite, analcite, and laumontite. Massive hydrocarbon expulsion of the Badaowan Formation source rock started during $13 \mathrm{Ma}$ to $8 \mathrm{Ma}$, and the hydrocarbons migrated into the Toutunhe sandstone reservoir via the Aika fault belt and the Jurassic-Cretaceous unconformity. The hydrocarbon emplacement brought in a large amount of organic acid and carbon dioxide produced by organic matter decarboxylation, which triggered the ferrocalcite and ferrodolomite cementation. Consequently, further porosity reduction was seen in the carbonate cemented facies that was found densified at about $9 \mathrm{Ma}$. The WDF had never been through densification. Almost all of the oil-containing inclusions were concentrated in the WDF and field drilling in the Kayindike area also showed that the oil saturation of the WDF is higher than those of the other two. Given the above, the WDF, with the low matrix content, well-developed chlorite film, and high content of detrital quartz, served as the effective oil-containing reservoir. In contrast, both the MTCF, accomplishing densification before hydrocarbon emplacement, and the CCF, enduring densification during hydrocarbon emplacement, had lower oil saturations (Figure 13). At the end of the Neogene, the paleo-oil reservoir of the Toutunhe Formation was destructed, from which hydrocarbons migrated through the vertical fault into the Ziniquanzi Formation. However, some paleo-oil reservoirs survived in the Toutunhe Formation [65].
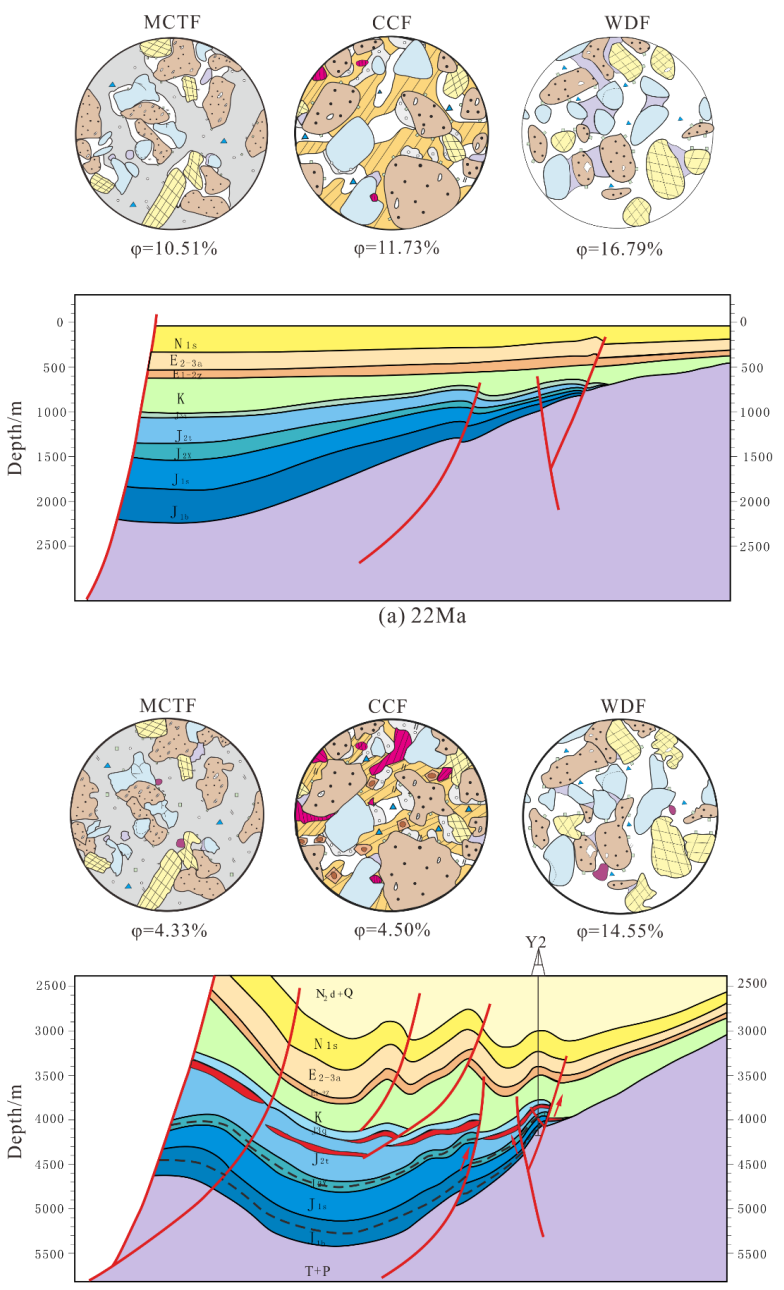

(b) $8 \mathrm{Ma}-$ Present day

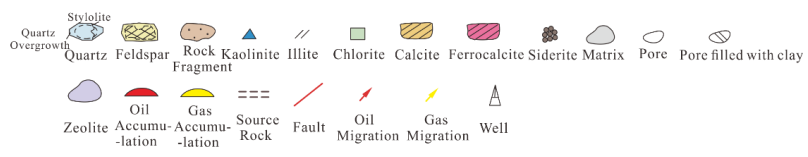

Figure 12. Reservoir-forming models of three lithofacies in the Toutunhe Formation. Tectonic evolution model of the Kayindike anticline was modified by the Xinjiang oil filed, CNPC. 

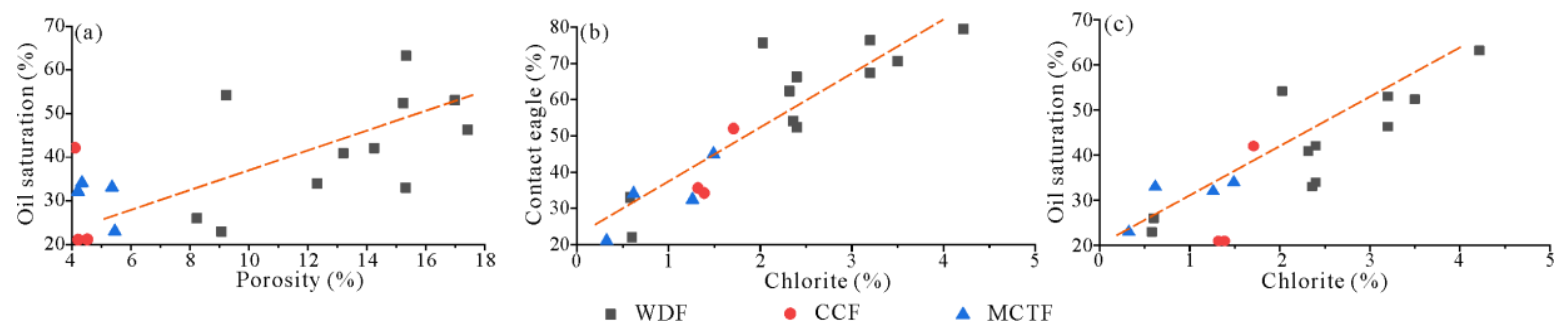

Figure 13. Plots of controlling factors for oil saturation of the reservoir in the Toutunhe Formation. (a) Relationship between the oil saturation and porosity; (b) contact eagle versus chlorite; (c) correlation between oil saturation and chlorite. CCF: carbonate cemented facies; MTCF: matrix-caused tightly compacted facies, WDF: weakly diagenetic reformed facies.

From the end of Paleogene to the Early Neogene, the maximum remaining formation pressure was $2.5 \mathrm{MPa}$ for the Toutunhe Formation in the Kayindike area of the Sikeshu Sag. Such weak over-pressurization indicated that the hydrocarbon expulsion failed to generate sufficient pressure to transport crude oil into the tight reservoir [65,66]. Hence, the CCF and the MTCF were associated with low oil contents (Figure 13a). For the Toutunhe sandstone, buoyancy is the main driver for hydrocarbon migration.

\subsection{Factors Controlling Reservoir-Forming Process of the Tight Sandstone}

The reservoir forming process of the Toutunhe Formation tight sandstone in the Kayindike area was mainly affected by the burial process and reservoir wettability. In cases of varied structural geologic settings, the burial evolution histories of formations were tremendously different, which directly resulted in the differentiation of the diagenetic modification intensity of sandstone. Therefore, the burial history to some extent controlled the reservoir quality. Specifically, the diagenetic modification intensity was decided by the burial rate and depth. The burial history curve of Well Y1 in the Kayindike area showed that the Sikeshu Sag was subjected to slow subsidence on an overall basis since Jurassic, with a subsidence rate of $8 \mathrm{~m} / \mathrm{Myr}[67,68]$. Due to the uplifting of the current North Tianshan area at the initial Neogene, the Toutunhe Formation started to subside rapidly at $25 \mathrm{Ma}$, with the subsidence rate increasing to $112 \mathrm{~m} / \mathrm{Myr}$ (according to the Xinjiang oilfield). To sum up, the burial process was mainly composed of the early shallow burial with slow subsidence and the late deep burial with rapid subsidence. Given this, the primary pore in the Toutunhe sandstone was well preserved during the early slow burial-the sandstone physical property degradation induced by compaction was fairly weak and the cementation and dissolution processes were limited [25]. However, as the rapid subsidence of formations began, densification was rapidly accomplished in the MTCF with a higher matrix content. As for the CCF and the WDF, they had relatively higher primary porosity and the porosity loss made by the rapid compaction was reduced, owing to the higher compaction resistance promoted by the high content of rigid minerals. Besides, the late rapid deep burial was relatively short-lived, so the thermochemical process did not severely impact the reservoir. It should be noted that rapid burial was highly likely to cause undercompaction and thus over-pressurization to protect primary pores. But this mechanism needed further investigation to confirm the presence of under-compaction in the Toutunhe Formation. The burial pattern featured the early slow shallow burial and late rapid deep burial of the Sikeshu Sag determines that the diagenetic modification of the sandstone reservoir was extremely limited, which in turn resulted in effective preservation of primary pores. Sharing the analogous provenance supplied and the sedimentary environment with the Sikeshu Sag, the Qigu fault-fold zone in the middle part of the South Junggar presents inferior reservoir quality, due to intensive compaction and cementation. The main reason was the burial pattern of the Qigu fault-fold zone of "sustained constant-rate deep burial plus late rapid uplifting" [67].

Wettability alteration, mainly triggered by the change of Zeta-potential on the mineral surface, had vital effects on the hydrocarbon emplacement in tight sandstone [69]. The 
surface of crude oil was often with negative potential [69]. Thus, if the authigenic mineral surface had positive potential, the oil and mineral would attract each other, which was manifested as lipophilicity [48]. By measuring the contact angle of 18 representative samples of the three facies and oil saturations of the 18 Jurassic sandstone samples of the Kayindike area, this research investigated the effects of diagenetic minerals on the reservoir wettability of the Jurassic reservoir in the South Junggar (Figure 13b,c). The measured contact angles are $13.5^{\circ}$ to $79.52^{\circ}$. Moreover, the contact angles of the WDF were $66.24^{\circ}$ to $79.52^{\circ}$ (fairly lipophilic), considerably higher than those of the other facies averaging $27.41^{\circ}$ (highly hydrophilic).

Clay minerals played a critical role in the wettability alteration of the Jurassic reservoir in the South Junggar, especially chlorite. In the WDF, the surfaces of feldspar and rock fragments often developed a flaky chlorite film. With the increasing chlorite film, the reservoir oil saturation grew, and a rising tendency was observed in the contact angle. The chlorite in the South Junggar Jurassic sandstone was mainly derived from the dissolution of volcanic rock fragments, smectite conversion, and plagioclase dissolution, associated with higher content of iron. The positive charge of excessive $\mathrm{Fe}^{2+}$ and $\mathrm{Mg}^{2+}$ in the flaky chlorite increased the positive potential on the reservoir pore surface (mineral surface), which consequently altered the reservoir wettability and promoted lipophilicity (Figure 13b). In addition, during the Toutunhe period, the climate was arid and hot, the salinity of the lake grew, and so did the eogenetic pore water. Under such circumstances, the formed chlorite naturally had higher lipophilicity, which was favorable for hydrocarbon emplacement (Figure 13c; [70]). The lipophilic chlorite film could also react with the crude oil to form a series of flocculating constituents to further reduce the viscous force of oil flow [48].

The over-pressurization system was also one of the important mechanisms affecting the reservoir's physical property. It could only protect the primary pores of the reservoir but also had decisive effects on hydrocarbon emplacement in tight sandstone. By paleo-pressure reconstruction based on fluid inclusions and numerical simulation, some scholars managed to confirm the presence of abnormally high pressure in the east and south of the Kayindike area during Paleogene-the remaining formation pressure was up to $25 \mathrm{MPa}$ in the Dushanzi area and that of the Xihu area could reach $37 \mathrm{Mpa}$. Such overpressurization was mainly related to under-compaction and tectonic compression $[65,66]$. The Kayindike area presented low remaining formation pressure and barely developed over-pressurization [66]. Accordingly, the formation process of the effective Toutunhe Formation reservoir in this area was more similar to that of conventional sandstone reservoirs, in which the driver for hydrocarbon accumulation was mainly buoyancy. This understanding was also supported by the fact that the facies with inferior physical properties (the matrix-caused tightly-compacted and carbonate cemented facies) had lower oil contents. During Cenozoic, the Sikeshu Sag was subjected to violent northward compression and the Aika structural belt was re-activated from the end of Paleogene to the early Neogene, which led to a series of shallow detachment and thrust faults, further releasing the pressure [71]. This might be one of the reasons for the under-development of over-pressurization in the Toutunhe Formation of the Kayindike area during that period.

\section{Conclusions}

(1) Due to the low intensity of the diagenetic modification, the Toutunhe Formation sandstone reservoir in the Kayindike area, the Sikeshu Sag at the southern margin of the Junggar Basin, is characterized by limited dissolution (average porosity of dissolution pore less than $3 \%$ ), low cement content (average content of cements less than $7 \%$ ), and greatly varying matrix content (average content of matrix reached $12.3 \%$ ). It has three facies, namely the matrix-caused tightly-compacted facies (MTCF, with high content of matrix, from $7 \%$ to $16.2 \%$ ), the carbonate-cemented facies (CCF, with high content of carbonate cement, from $12 \%$ to $20.29 \%$ ), and the weakly diagenetically-reformed facies (WDF). The former two facies reached the porosity limit of tight sandstone at $18 \mathrm{Ma}$ and $9 \mathrm{Ma}$, respectively. The WDF has not been through densification, due to 
its low matrix content (average $4.09 \%$ ) and high contents of detrital quartz (average $28.75 \%$ ) and chlorite films (average $2.2 \%$ ).

(2) The Toutunhe sandstone in the Kayindike area had been through only one stage of low-maturity-hydrocarbon emplacement, charging in $13 \mathrm{Ma}$ to $8 \mathrm{Ma}$. The Badaowan Formation source rock started to experience massive hydrocarbon expulsion at $13 \mathrm{Ma}$ to $8 \mathrm{Ma}$ and the expelled hydrocarbons migrated into the Toutunhe sandstone reservoir via the Aika fault belt. At this time, porosities of the CCF and the MTCF deceased to $10 \%$, and most hydrocarbons were driven by the buoyancy to flow into the highporosity high-permeability WDF. At the end of Neogene, the hydrocarbons in the WDF migrated into the Ziniquanzi Formation, due to tectonic compression, while some paleo-oil reservoirs remained in the WDF.

(3) The main control factors of the reservoir-forming process of the Toutunhe sandstone in the Kayindike area were the burial process and reservoir wettability. The burial pattern of the Toutunhe Formation was composed of "early slow, shallow burial and late rapid, deep burial". The early shallow burial with slow subsidence limited the modification intensity of compaction, cementation, and dissolution, while the late rapid subsidence avoided severe damage to the reservoir quality by thermochemical effects. High content of chlorite films increased the lipophilicity of the sandstone reservoir effectively (average content of chlorite films reached 1.2\%). The syndepositional volcanism of the Toutunhe Formation promoted the formation of chlorite films by offering an alkaline diagenetic environment and iron-containing leading minerals. The sandstone reservoir of the WDF was the most favorable reservoir, due to its characteristics of high porosity (average porosity reached $13.04 \%$ ), high permeability $(2.77 \mathrm{mD})$, low pore capillary pressure, good pore connectivity, and the presence of chlorite films that further enhanced the reservoir lipophilicity.

Author Contributions: Conceptualization, T.Z. and C.W.; methodology, X.G.; software, X.G.; investigation, J.W.; resources, B.Y.; data curation, W.Z.; writing-original draft preparation, W.Z.; writing-review and editing, W.Z.; visualization, B.Y.; funding acquisition, B.Y. All authors have read and agreed to the published version of the manuscript.

Funding: This research was funded by the National Science and Technology Major Project of China, Grant/Number: 2017ZX05008-001.

Institutional Review Board Statement: Not applicable.

Informed Consent Statement: Not applicable.

Data Availability Statement: The data relevant with this study can be accessed by contacting the corresponding author.

Conflicts of Interest: The authors declare no conflict of interest.

\section{References}

1. Li, A.; Ding, W.; Jiu, K.; Wang, Z.; Wang, R.; He, J. Investigation of the pore structures and fractal characteristics of marine shale reservoirs using NMR experiments and image analyses: A case study of the Lower Cambrian Niutitang Formation in northern Guizhou Province, South China. Mar. Pet. Geol. 2018, 89, 530-540. [CrossRef]

2. Morad, S.; Al-Ramadan, K.; Ketzer, J.M.; De Ros, L.F. The impact of diagenesis on the heterogeneity of sandstone reservoirs: A review of the role of depositional facies and sequence stratigraphy. AAPG Bull. 2010, 94, 1267-1309. [CrossRef]

3. Fisher, Q.J.; Haneef, J.; Grattoni, C.A.; Allshorn, S.; Lorinczi, P. Permeability of fault rocks in siliciclastic reservoirs: Recent advances. Mar. Pet. Geol. 2018, 91, 29-42. [CrossRef]

4. Dashti, R.; Rahimpour-Bonab, H.; Zeinali, M. Fracture and mechanical stratigraphy in naturally fractured carbonate reservoirs-A case study from Zagros region. Mar. Pet. Geol. 2018, 97, 466-479. [CrossRef]

5. Yue, D.; Wu, S.; Xu, Z.; Xiong, L.; Chen, D.; Ji, Y.; Zhou, Y. Reservoir quality, natural fractures, and gas productivity of upper Triassic Xujiahe tight gas sandstones in western Sichuan Basin, China. Mar. Pet. Geol. 2018, 89, 370-386. [CrossRef]

6. Desbois, G.; Urai, J.L.; Kukla, P.A.; Konstanty, J.; Baerle, C. High-resolution 3D fabric and porosity model in a tight gas sandstone reservoir:A new approach to investigate microstructures from $\mathrm{mm}$ - to nm-scale combining argon beam cross-sectioning and SEM imaging. J. Pet. Sci. Eng. 2011, 78, 243-257. [CrossRef] 
7. Xiao, D.; Lu, Z.; Jiang, S.; Lu, S. Comparison and integration of experimental methods to characterize the full-range pore features of tight gas sandstone-A case study in Songliao Basin of China. J. Nat. Gas. Sci. Eng. 2016, 34, 1412-1421. [CrossRef]

8. Sakhaee-Pour, A.; Bryant, S.L. Effect of pore structure on the producibility of tight-gas sandstones. AAPG Bull. 2014, 98, 663-694. [CrossRef]

9. Stroker, T.M.; Harris, N.B.; Crawford Elliott, W.; Marion Wampler, J. Diagenesis of a tight gas sand reservoir: Upper Cretaceous Mesaverde Group, Piceance Basin, Colorado. Mar. Pet. Geol. 2013, 40, 48-68. [CrossRef]

10. Walderhaug, O.; Eliassen, A.; Aase, N.E. Prediction of Permeability in Quartz-Rich Sandstones: Examples from the Norwegian Continental Shelf and the Fontainebleau Sandstone. J. Sediment. Res. 2012, 82, 899-912. [CrossRef]

11. Xiao, D.; Jiang, S.; Thul, D.; Lu, S.; Zhang, L.; Li, B. Impacts of clay on pore structure, storage and percolation of tight sandstones from the Songliao Basin, China: Implications for genetic classification of tight sandstone reservoirs. Fuel 2018, 211, 390-404. [CrossRef]

12. Saïag, J.; Brigaud, B.; Portier, É.; Desaubliaux, G.; Bucherie, A.; Miska, S.; Pagel, M. Sedimentological control on the diagenesis and reservoir quality of tidal sandstones of the Upper Cape Hay Formation (Permian, Bonaparte Basin, Australia). Mar. Pet. Geol. 2016, 77, 597-624. [CrossRef]

13. Li, P.; Zheng, M.; Bi, H.; Wu, S.; Wang, X. Pore throat structure and fractal characteristics of tight oil sandstone: A case study in the Ordos Basin, China. J. Pet. Sci. Eng. 2017, 149, 665-674. [CrossRef]

14. Lai, J.; Wang, G.; Cai, C.; Fan, Z.; Wang, S.; Chen, J.; Luo, G. Diagenesis and reservoir quality in tight gas sandstones: The fourth member of the Upper Triassic Xujiahe Formation, Central Sichuan Basin, Southwest China. Geol. J. 2018, 53, 629-646. [CrossRef]

15. Taylor, T.R.; Giles, M.R.; Hathon, L.A.; Diggs, T.N.; Braunsdorf, N.R.; Birbiglia, G.V.; Kittridge, M.G.; Macaulay, C.I.; Espejo, I.S Sandstone diagenesis and reservoir quality prediction: Models, myths, and reality. AAPG Bull. 2010, 94, 1093-1132. [CrossRef]

16. Bjørlykke, K.; Jahren, J. Open or closed geochemical systems during diagenesis in sedimentary basins: Constraints on mass transfer during diagenesis and the prediction of porosity in sandstone and carbonate reservoirs. AAPG Bull. 2012, 96, $2193-2214$. [CrossRef]

17. Yuan, G.; Cao, Y.; Gluyas, J.; Li, X.; Xi, K.; Wang, Y.; Jia, Z.; Sun, P.; Oxtoby, N.H. Feldspar dissolution, authigenic clays, and quartz cements in open and closed sandstone geochemical systems during diagenesis: Typical examples from two sags in Bohai Bay Basin, East China. AAPG Bull. 2015, 99, 2121-2154. [CrossRef]

18. He, H.; Zhi, D.; Lei, D.; Yang, D.; Xiao, L.; Yuan, B.; Qi, X.; Zhao, J. Strategic breakthrough in Gaoquan anticline and exploration assessment on lower assemblage in the southern margin of Junggar Basin. China Pet. Explor. 2019, 24, 137-146.

19. Jinhu, D.; Xiangbo, L.; Hongping, B.; Wanglin, X.; Yating, W.; Junping, H.; Hongbo, W.; Rong, W.; Jing, C. Geological conditions of natural gas accumulation and new exploration areas in the Mesoproterozoic to Lower Paleozoic of Ordos Basin, NW China. Pet. Explor. Dev. 2019, 5, 866-882.

20. Guo, Z.; Wu, C.; Zhang, Z.; Chen, W. Tectonic Control on Hydrocarbon Accumulation and Prospect for Large Oil-Gas Field Exploration in the Southern Junggar Basin. Geol. J. China Univ. 2011, 17, 185-195.

21. Sun, J.; Song, Y.; Xue, J.; Fei, L.; Song, M.; Chang, Q. Deep Tight Reservoir Developmen Characteristics and Evolution Model of Badaowan Formation in Mosuowan-Mobei Area, Junggar Basin. Nat. Gas Geosci. 2015, 26, 2275-2280.

22. Deng, H. Research on Sedimentary Facies and Reservoir Characteristics of Badaowan Formation in Baikouquan Oil Field, Junggar Basin. Master's Thesis, Xinjiang University, Ürümqi, China, 2015.

23. Cao, B.; Luo, X.; Zhang, L.; Sui, F.; Lin, H.; Lei, Y. Diagenetic evolution of deep sandstones and multiple-stage oil entrapment: A case study from the Lower Jurassic Sangonghe Formation in the Fukang Sag, central Junggar Basin (NW China). J. Pet. Sci. Eng. 2017, 152, 136-155. [CrossRef]

24. Yu, J.; Ren, W.; Wang, W.; Wang, S.; Liu, N.; Ouyang, X. Formation Mechanism of Toutunhe Abnormal Pressure of Middle Jurassic in Fudong Slope Area, Junggar Basin. Xinjiang Pet. Geol. 2015, 36, 521-525.

25. Lin, T.; Li, W.; Sun, P.; Shen, Y.; Wang, D. Factors influencing deep favorable reservoirs on the southern margin of Junggar Basin. Geol. Bull. China 2013, 32, 1461-1470.

26. Fang, Y.; Wu, C.; Guo, Z.; Hou, K.; Dong, L.; Wang, L.; Li, L. Provenance of the southern Junggar Basin in the Jurassic: Evidence from detrital zircon geochronology and depositional environments. Sediment. Geol. 2015, 315, 47-63. [CrossRef]

27. Chen, H.; Gu, S.; Zhang, S.; Chen, L.; Ji, H. Nat. Gas Geosci. 2015, 26, $33-43$.

28. Shan, X.; Xu, Y.; Tang, Y.; Chen, N.; Guo, H.; Guo, S. Diagenesis and effect on physical property of lower Jurassic Badaowan Formation in Mobei- Mosuowan Area, Junggar Basin. Xinjiang Pet. Geol. 2015, 36, 401-408.

29. Sun, J.; Xue, J.; Zeng, D.; Wang, R.; Wang, F.; Li, H. Deep tight reservoir characteristics and main controlling factors of Badaowan formation in the central Junggar Basin. J. Northeast Pet. Univ. 2017, 41, 1-10.

30. Luo, B.; Yang, Y.; Luo, W.; Wen, L.; Wang, W.; Chen, K. Controlling factors of Dengying Formation reservoirs in the central Sichuan paleo-uplift. Pet. Res. 2017, 2, 54-63. [CrossRef]

31. Zhao, X.; Shan, X.; Hao, G.; He, W.; Liang, Y. Sedimentary facies and evaluation of oil sand reservoirs from Jurassic Toutunhe Formation in Kalazha Anticline of Junggar Basin, China. J. Earth Sci. Environ. 2017, 39, 419-427.

32. Carroll, A.R.; Yunhai, L.; Graham, S.A.; Xuchang, X.; Hendrix, M.S.; Jinchi, C.; McKnight, C.L. Junggar basin, northwest China: Trapped Late Paleozoic ocean. Tectonophysics 1990, 181, 1-14. [CrossRef]

33. Allen, M.B.; Windley, B.F.; Chi, Z.; Zhong-Yan, Z.; Guang-Rei, W. Basin evolution within and adjacent to the Tien Shan range, NW China. J. Geol. Soc. 1991, 148, 369-378. [CrossRef] 
34. Allen, M.B.; Windley, B.F.; Zhang, C. Palaeozoic collisional tectonics and magmatism of the Chinese Tien Shan, central Asia. Tectonophysics 1993, 220, 89-115. [CrossRef]

35. Hendrix, M.S. Evolution of Mesozoic sandstone compositions, southern Junggar, northern Tarim, and western Turpan basins, Northwest China: A detrital record of the ancestral Tian Shan. J. Sediment. Res. 2000, 70, 520-532. [CrossRef]

36. Han, B.; He, G.; Wang, X.; Guo, Z. Late Carboniferous collision between the Tarim and Kazakhstan-Yili terranes in the western segment of the South Tian Shan Orogen, Central Asia, and implications for the Northern Xinjiang, western China. Earth-Sci. Rev. 2011, 109, 74-93. [CrossRef]

37. Jolivet, M.; Heilbronn, G.; Robin, C.; Barrier, L.; Bourquin, S.; Guo, Z.; Jia, Y.; Guerit, L.; Yang, W.; Fu, B. Reconstructing the Late Palaeozoic-Mesozoic topographic evolution of the Chinese Tian Shan: Available data and remaining uncertainties. Adv. Geosci. 2013, 37, 7-18. [CrossRef]

38. Yang, W.; Jolivet, M.; Dupont-Nivet, G.; Guo, Z.; Zhang, Z.; Wu, C. Source to sink relations between the Tian Shan and Junggar Basin (northwest China) from Late Palaeozoic to Quaternary: Evidence from detrital U-Pb zircon geochronology. Basin Res. 2013, 25, 219-240. [CrossRef]

39. Fang, Y.; Wu, C.; Wang, Y.; Hou, K.; Guo, Z. Topographic evolution of the Tianshan Mountains and their relation to the Junggar and Turpan Basins, Central Asia, from the Permian to the Neogene. Gondwana Res. 2019, 75, 47-67. [CrossRef]

40. Wang, J.; Wu, C.; Li, Z.; Zhu, W.; Zhou, T.; Wu, J.; Wang, J. Whole-rock geochemistry and zircon Hf isotope of Late CarboniferousTriassic sediments in the Bogda region, NW China: Clues for provenance and tectonic setting. Geol. J. 2018, 54, $1853-1877$. [CrossRef]

41. Li, J. The Structural Control of Oil and Gas Trasporting Effectiveness in Sikeshu Depression. Master's Thesis, China University of Petroleum (Huadong), Qingdao, China, 2017.

42. Yuan, B.; Dong, X.; Guan, X.; Zhou, T.; Wang, X.; Wei, L.; Zhao, J.; Feng, G.; Wu, C. Analysis of characterictics of tight sandstone reservoir with porous- fissure dual medium in Toutunhe Formation of Sikeshu Sag. Acta Sci. Nat. Univ. Pekin. 2020, 3, 449-459.

43. Xi, K.; Cao, Y.; Haile, B.G.; Zhu, N.; Liu, K.; Wu, S.; Hellevang, H. Diagenetic variations with respect to sediment composition and paleo-fluids evolution in conglomerate reservoirs: A case study of the Triassic Baikouquan Formation in Mahu Sag, Junggar Basin, Northwestern China. J. Pet. Sci. Eng. 2020, 107943. [CrossRef]

44. Morad, S.; Al-Aasm, I.S.; Ramseyer, K.; Marfil, R.; Aldahan, A.A. Diagenesis of carbonate cements in Permo-Triassic sandstones from the Iberian Range, Spain: Evidence from chemical composition and stable isotopes. Sediment. Geol. 1990, 67, 281-295. [CrossRef]

45. Friedman, I.; O'Brien, J.R. Compilation of Stable Isotope Fractionation Factors of Geochemical Interest in Data of Geochemistry; US Geological Survey Professional Paper; US Government Printing Office: Washington, DC, USA, 1977.

46. Luo, L.; Gao, X.; Meng, W.; Tan, X.; Shao, H.; Xiao, C. The origin and alteration of calcite cement in tight sandstones of the Jurassic Shishugou Group, Fukang Sag, Junggar Basin, NW China: Implications for fluid-rock interactions and porosity evolution. Aust. J. Earth. Sci. 2018, 65, 427-445. [CrossRef]

47. Xia, C.; Wilkinson, M.; Haszeldine, S. Petroleum emplacement inhibits quartz cementation and feldspar dissolution in a deeply buried sandstone. Mar. Pet. Geol. 2020, 118, 104449. [CrossRef]

48. Xi, K.; Cao, Y.; Liu, K.; Wu, S.; Yuan, G.; Zhu, R.; Zhou, Y.; Hellevang, H. Geochemical constraints on the origins of calcite cements and their impacts on reservoir heterogeneities: A case study on tight oil sandstones of the Upper Triassic Yanchang Formation, southwestern Ordos Basin, China. AAPG Bull. 2019, 103, 2447-2485. [CrossRef]

49. Marcussen, Ø.; Maast, T.E.; Mondol, N.H.; Jahren, J.; Bjørlykke, K. Changes in physical properties of a reservoir sandstone as a function of burial depth-The Etive Formation, northern North Sea. Mar. Pet. Geol. 2010, 27, 1725-1735. [CrossRef]

50. Nabawy, B.S.; Géraud, Y.; Rochette, P.; Bur, N. Pore-throat characterization in highly porous and permeable sandstones. AAPG Bull. 2009, 93, 719-739. [CrossRef]

51. Tobin, R.C.; McClain, T.; Lieber, R.B.; Ozkan, A.; Banfield, L.A.; Marchand, A.M.E.; McRae, L.E. Reservoir quality modeling of tight-gas sands in Wamsutter field: Integration of diagenesis, petroleum systems, and production data. AAPG Bull. 2010, 94, 1229-1266. [CrossRef]

52. Bjørlykke, K. Clay mineral diagenesis in sedimentary basins-A key to the prediction of rock properties. Examples from the North Sea Basin. Clay Min. 1998, 33, 14-34. [CrossRef]

53. Schmid, S.; Worden, R.H.; Fisher, Q.J. Diagenesis and reservoir quality of the Sherwood Sandstone (Triassic), Corrib Field, Slyne Basin, west of Ireland. Mar. Pet. Geol. 2004, 21, 299-315. [CrossRef]

54. Aminul Islam, M. Diagenesis and reservoir quality of Bhuban sandstones (Neogene), Titas Gas Field, Bengal Basin, Bangladesh. J. Asian Earth Sci. 2009, 35, 89-100. [CrossRef]

55. Thyberg, B.; Jahren, J.; Winje, T.; Bjørlykke, K.; Faleide, J.I.; Marcussen, Ø. Quartz cementation in Late Cretaceous mudstones, northern North Sea: Changes in rock properties due to dissolution of smectite and precipitation of micro-quartz crystals. Mar. Pet. Geol. 2010, 27, 1752-1764. [CrossRef]

56. Zhu, S.; Cui, H.; Jia, Y.; Zhu, X.; Tong, H.; Ma, L. Occurrence, composition, and origin of analcime in sedimentary rocks of non-marine petroliferous basins in China. Mar. Pet. Geol. 2020, 113, 104164. [CrossRef]

57. Remy, R.R.; Ferrell, R.E. Distribution and origin of analcime in marginal lacustrine mudstones of the Green River Formation, south-central Uinta basin, Utah. Clays Clay Min. 1989, 37, 419-432. [CrossRef] 
58. English, P.M. Formation of analcime and moganite at Lake Lewis, Central Australia: Significance of groundwater evolution in diagenesis. Sediment. Geol. 2001, 143, 219-244. [CrossRef]

59. Bish, D.L.; Ming, D.W. Reviews in mineralogy \& geochemistry: Occurrence, properties, applications. Nat. Zeolites Mineral. Soc. Am. 2001, 45, 1-10.

60. Carvalho, A.D.S.G.; De Ros, L.F. Diagenesis of Aptian sandstones and conglomerates of the Campos Basin. J. Pet. Sci. Eng. 2015, 125, 189-200. [CrossRef]

61. Zhang, J.; Cui, Q.; Hu, H.; Kang, Y.; Guo, Z. Hydrocarbon accumulation conditions of the Lower assemblage in Sikeshu Sag, the Southern margin of Junggar Basin. Xinjiang Geol. 2016, 34, 269-274.

62. Lin, X.; Qin, J.; Nie, W.; Ni, Q. Hydrocarbon accumulation pattern of Kayindike region in Southern Junggar Basin. Pet. Geol. Exp. 2014, 36, 304-309.

63. Chen, J.; Wang, X.; Deng, C.; Zhao, Z.; Ni, Y.; Sun, Y.; Yang, H.; Wang, H.; Liang, D. Investigation of typical reservoirs and occurrence regularity of crude oils in the Souther margin of Junggar Basin, Northwestern China. Acta Pet. Sin. 2016, 37, 415-429.

64. Dou, W.; Liu, L.; Wu, K.; Xu, Z.; Liu, X.; Feng, X. Diagenetic heterogeneity, pore throats characteristic and their effects on reservoir quality of the Upper Triassic tight sandstones of Yanchang Formation in Ordos Basin, China. Mar. Pet. Geol. 2018, 98, $243-257$. [CrossRef]

65. Qin, J. Research on Source Rocks Condition and Oil Migration of the Middle-Upper Combination in Sikeshu Sag in the Southern Margin of Junggar Basin. Master's Thesis, Changjiang University, Jingzhou, China, 2014.

66. Liu, W. Formation Mechanism and Evolution Characteristics of the Lower Anomalous High Pressure in the Southern Margin of the Junggar Basin. Master's Thesis, Xi'an Shiyou University, Xi'an, China, 2019.

67. Huang, J. The Southern Margin of Junggar Basin Hydrocarbon Source Rock Thermal Evolution History of Hydrocarbon Generation and Oil and Gas Source Analysis. Master's Thesis, Xi'an Shiyou University, Xi'an, China, 2017.

68. Hu, H.; Zhang, J.; Tian, X.; Zhuo, Q.; Jia, C.; Guo, Z. Evolution of the deeply buried Jurassic reservoirs in the southern Junggar Basin, NW China: Evidences from the Well DS-1. Pet. Res. 2017, 2, 247-263. [CrossRef]

69. Hiorth, A.; Cathles, L.M.; Madland, M.V. The Impact of Pore Water Chemistry on Carbonate Surface Charge and Oil Wettability. Transp. Porous Media 2010, 85, 1-21. [CrossRef]

70. Alotaibi, M.B.; Nasralla, R.A.; Din, H.A.N.E. Wettability Studies Using Low-Salinity Water in Sandstone Reservoirs. SPE. Reserv. Eval. Eng. 2011, 4, 725-731. [CrossRef]

71. Yang, D.; Yan, G.; Zhou, T.; Li, Y. Coupling Relationship Between Densification Process and Hydrocarbon Charging Timing in Sandstone Reservoirs of Badaowan Formation in Qigu Fault-Fold Belt, Junggar Basin. Xinjiang Pet. Geol. 2020, 41, 55-66. 